\title{
The Role of Social Dominance, Machiavellianism, and Emotional Manipulation on Profit Management
}

\author{
Hassan Sadeghpour \\ PhD Student in Accounting, Karaj Branch, Islamic Azad University, Karaj, \\ Iran \\ Hassan.sadeghpour@yahoo.com \\ Mahdi Moradzadehfarg * \\ Associate Professor, Department of Accounting, Karaj Branch, Islamic Azad \\ University, Karaj, Iran (Corresponding Author) \\ Moradzadehfard@yahoo.com \\ Bahram Hemati \\ Assistant Professor, Department of Accounting, Karaj Branch, Islamic Azad \\ University, Karaj, Iran., Hemati_b@yahoo.com
}

\begin{abstract}
:
Investigating the psychological aspects of unethical behaviors is one of the most important issues in the field of accounting and finance. This study aimed to investigate the effect of psychological variables including social dominance, Machiavellianism, and emotional manipulation on profit management. The research was conducted in 2020 by collecting data with simple Non-Probability sampling method convenience. For this purpose, a sample of 401 accounting experts, accounting heads, and financial managers of the firms listed in the Stock Market was selected. The results were obtained from structural equations. They show that social dominance, emotional manipulation, and Machiavellianism have a positive effect on the willingness towards opportunistic profit management. In the efficient mode of the tendency towards profit management, two variables of social dominance and emotional manipulation have a positive effect on the tendency towards profit management, but the effect of Machiavellianism on this tendency is refuted. Furthermore, Machiavellianism affects profit management positively and indirectly through social dominance and emotional manipulation. The results show that management motivation for profit management is influenced by behavioral, organizational, and
\end{abstract}


Semiannually journal of Value \& Behavioral Accounting dof $10.52547 / \mathrm{aapc} .5 .10 .351$

psychological characteristics. The research evidence enhances our understanding of the effect of behavioral characteristics of management on decisions on profit management.

Keywords: Social Dominance, Machiavellianism, Emotional Manipulation, profit management

\section{Copyrights (c) (1)}

This license only allowing others to download your works and share them with others as long as they credit you, but they can't change them in any way or use them commercial. 


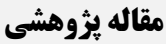

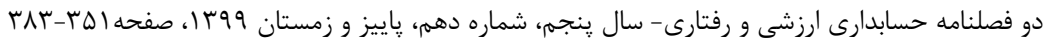

\section{نقش متغير هاى تسلط اجتماعى، ماكياوليسم و دستكارى عاطفى بر

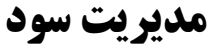

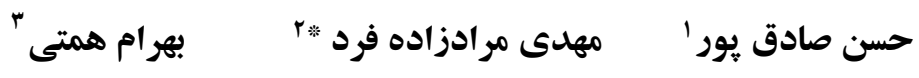

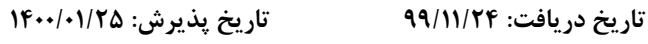

\begin{abstract}
جكيده
بررسى جنبههاى روانشناختى در رفتارهاى غيراخلاقى يكى از موضوعات مهم در حوزه حسابدارى و مالى است. هدف اين تحقيق بررسى تاثير متغيرهاى روانشناختى از جمله تسلط اجتماعى،

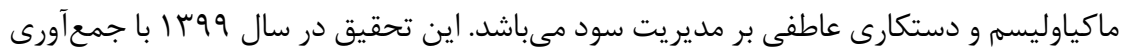
دادهها به روش نمونه ميرى غير احتمالى در دسترس انجام گرفت و براى اين منظور، نمونهاى از 1 • ن نفر از كارشناسان حسابدارى، روئساى حسابدارى و مديران مالى شركتهاى يذيرفته شده در بورس اوراق بهادار انتخاب شدند. نتايج اين تحقيق با بكارگيرى معادلات ساختارى انجام كرفت. يافتهها نشان مىدهد كه تسلط اجتماعى،دستكارى عاطفى و ماكياوليسم تاثير مثبتى بر تمايل به مديريت سود در حالت فرصت طلبانه دارد. تمايل به مديريت سود در حالت كارا، دو متغير تسلط اجتماعى و دستكارى عاطفى تاثير مثبت بر تمايل به مديريت سود داشته و اثر ماكياوليسم بر تمايل به مديريت سود رد شده است. هم جنين، ماكياوليسم به واسطه تسلط اجتماعى و دستكارى عاطفى اثر غير مستقيم و مثبت بر مديريت سود دارد. نتايج اين يزوهش

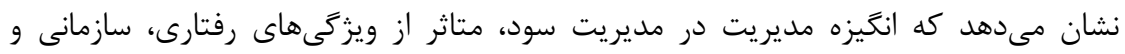
روانشناختى است. شواهد اين تحقيق درك و آكاهى درباره تاثير مشخصههاى رفتارى مديريت مديت بر مير تصميم گيرى هاى مديريت سود را افزايش مى دهد. وازَان كليدى: ماكياوليسم، دستكارى عاطفى ، تسلط اجتماعى و مديريت سود

\footnotetext{
'دانشجوى دكتراى حسابدارى، واحد كرج، دانشگاه آزاد اسلامى، كرج، ايران.

Hassan.sadeghpour@yahoo.com

ז'دانشيار، گروه حسابدارى، واحد كرج،دانشگاه آزاد اسلامى، كرج، ايران (نويسنده مسئول)،

Moradzadehfard@yahoo.com

"استاديار، كروه حسابدارى، واحد كرج،دانشعاه آزاد اسلامى، كرج، ايران Hemati_b@yahoo.com
} 


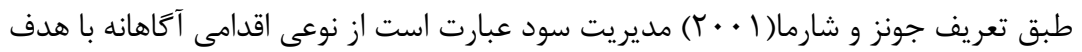
طبيعى نشان دادن سود شركت به يك سطح مطلوب و مورد نظر. آنها معتقدند مديريت سود

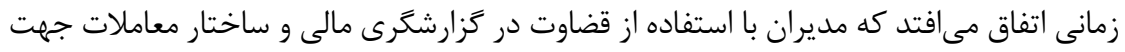
گمراه نمودن برخى از ذينفعان دربارهى عملكرد اقتصادى شركت درگزارشخرى مالى تغيير ايجاد

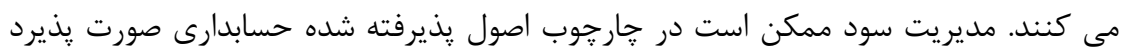
اما مسائل مربوط به عدم رعايت اصول اخلاقى كماكان وجود دارد زيرا بسيارى از استفاده كنندكان به صورتهاى مالى به عنوان منبعى براى تصميم گيرى هاى اقتصادى خود اتكا مى كنند و مديريت

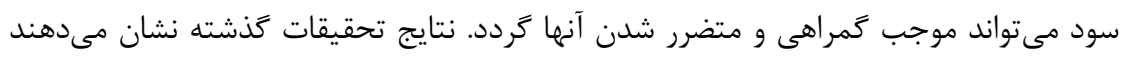
كه مديريت سود به عنوان يكى رفتار غيراخلاقى، ريشه در موضوعات اخلاقى و روانشناختى دارد.

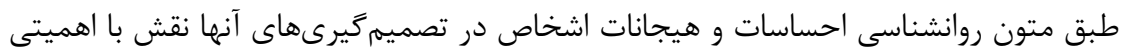
را ايفا مىنمايد. اين مهمم تا آنجاست كه تحقيقات در حوزيى روانشناسى نشان دادند كه قضاوت

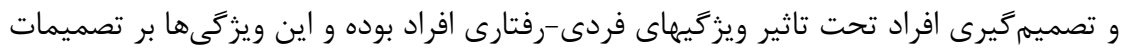

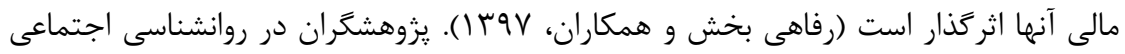

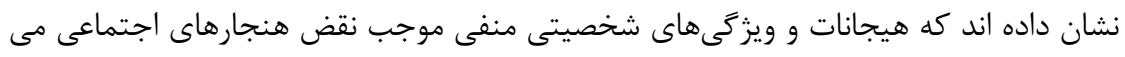

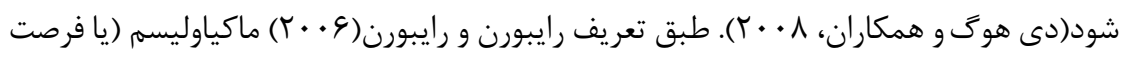

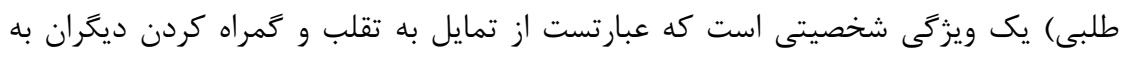

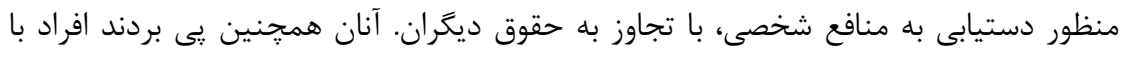

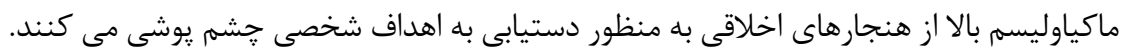

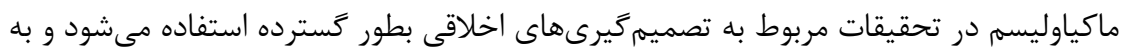

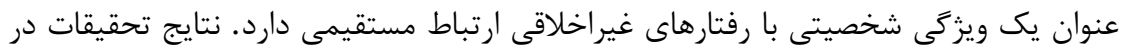

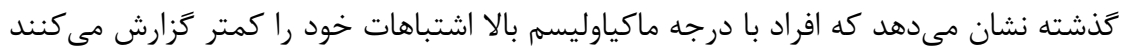
و بيشتر به دنبال رفتارهاى غيراخلاقى هستند (رويز پالومينو و بانان گومز،

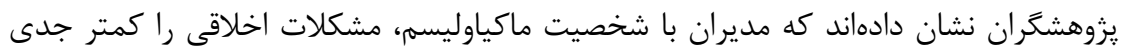
مى گيرند. از اين رو ماكياوليسم رابطه منفى با تصميمخيرى اخلاقى دارد (وربركى و همكاران، 999199). دستكارى عاطفى ' بعبارتى همان جنبه منفى هوش هيجانى است. هوش هيجانى

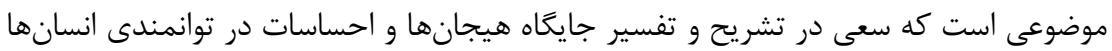
دارد. در واقع پيش بينى كننده موفقيت فرد در زندگى است زيرا نشان دهندهى عملكرد فرد در

${ }^{1}$ Emotional Manipulation 
دكتر مرادزاده و همكاران، نقش متغيرهاى تسلط اجتماعى، ماكياوليسم و دستكارى عاطفى بر مديريت سود سهب

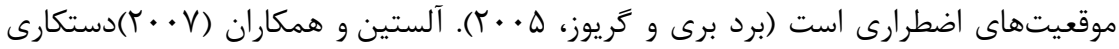

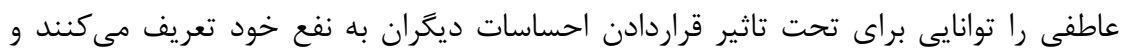

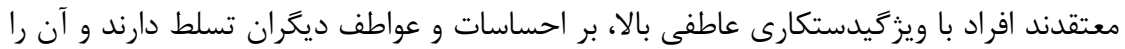
به نفع خود مديريت مىنمايند. مطالعات كذشته نشان مى دهد كه ميان هوش هيجانى و رفتار هائ

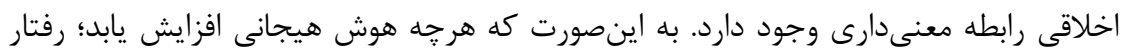

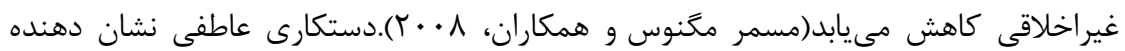

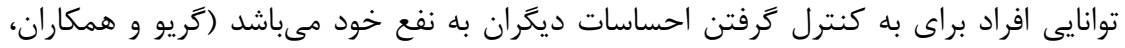

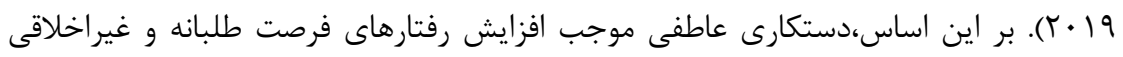

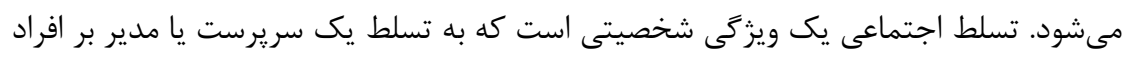

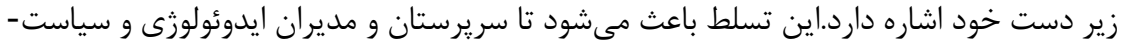

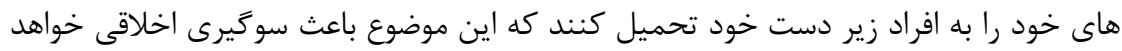

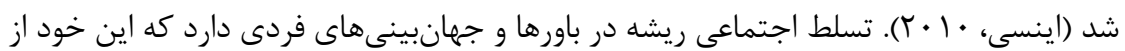

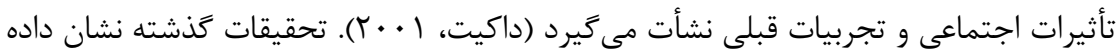

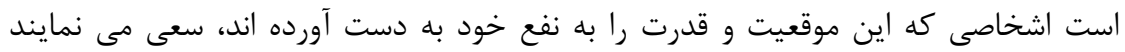

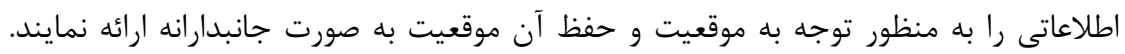

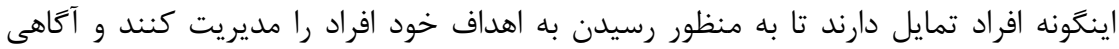

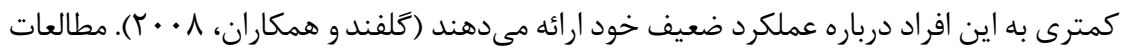

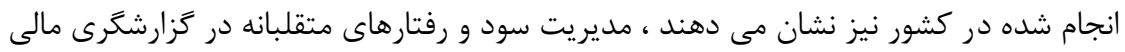

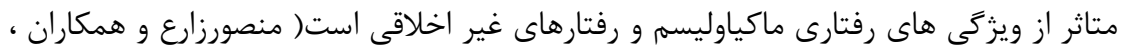

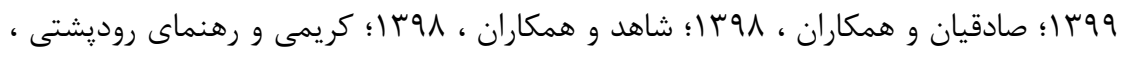

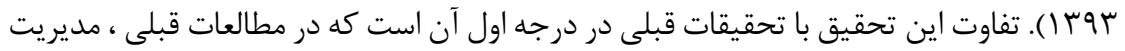

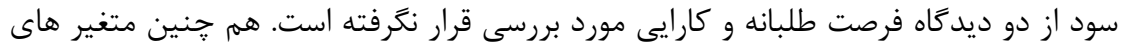

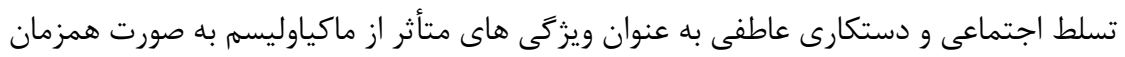

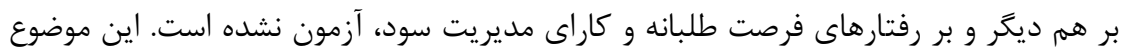

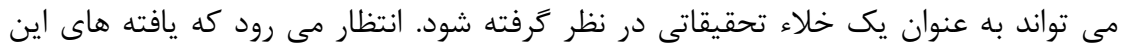

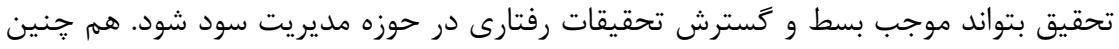

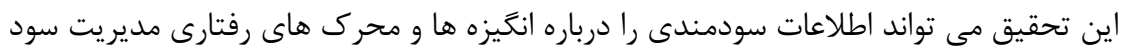

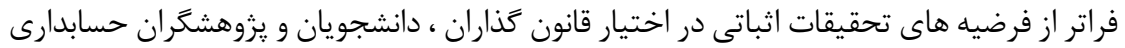

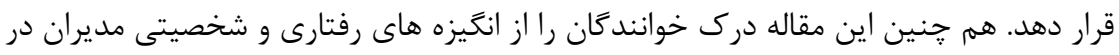

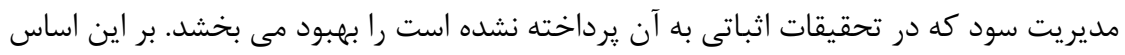


در اين مقاله، نويسندكان سعى دارند به دليل اهميت و ضرورت موضوع رفتار و انخيزههاى رفتارى

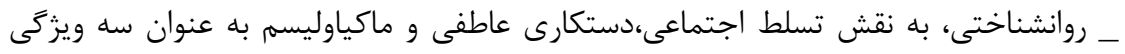

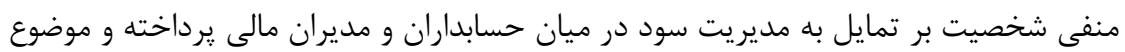
را مورد بررسى قرار دهند.

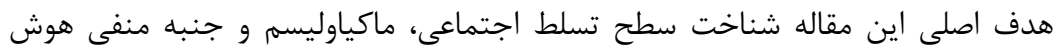

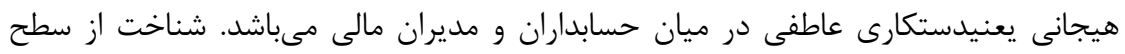

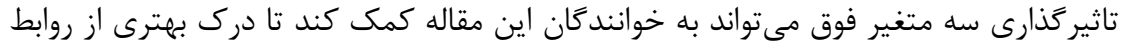

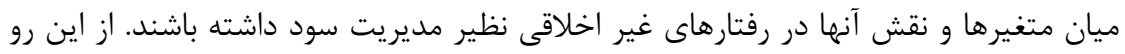

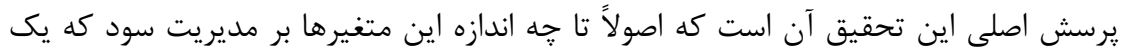

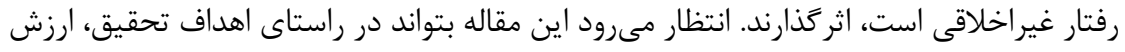

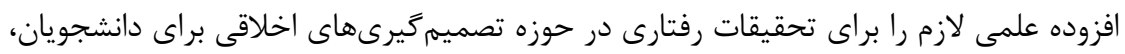

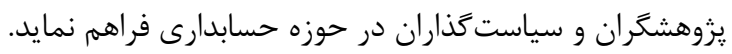

\section{r-مبانى نظرى وييشنيه يزوهش

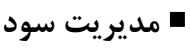

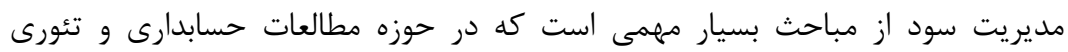

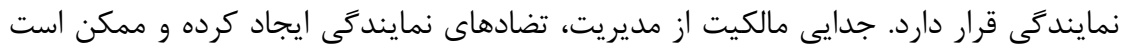

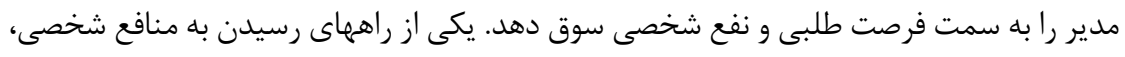

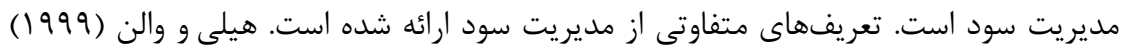

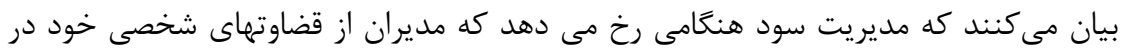

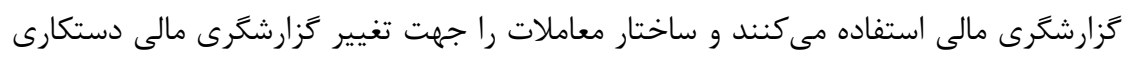

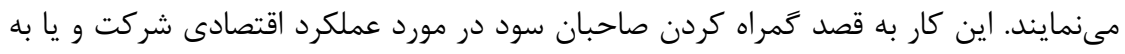

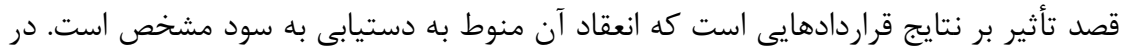

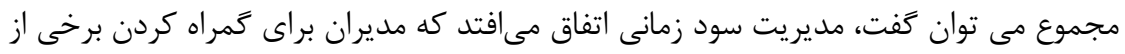

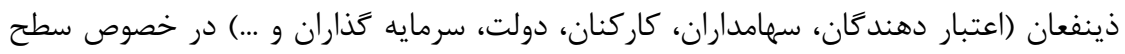

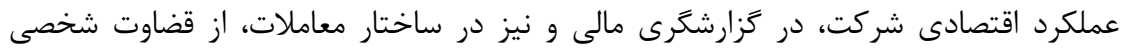

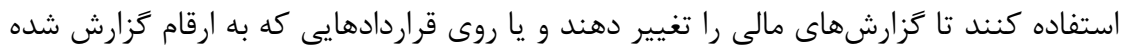

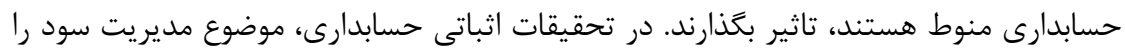


از دو ديدكاه فرصتطلبانه' و كارايى' مورد مطالعه و بررسى قراركرفته است. مديريت سود

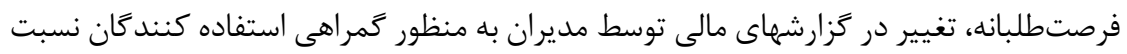

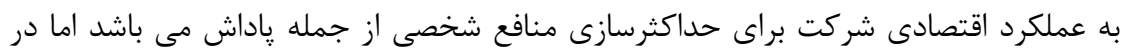

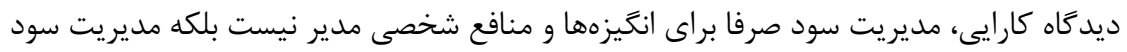

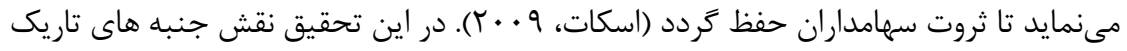

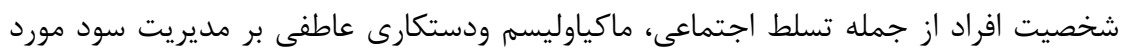
مطالعه قرار خرفته است.

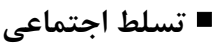

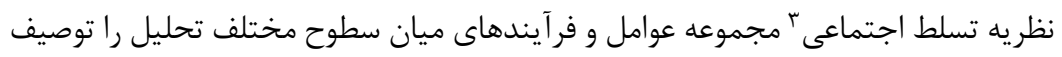

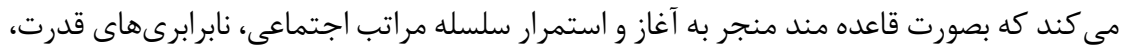

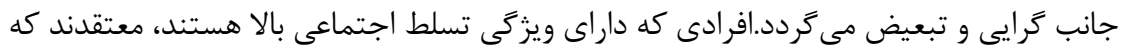

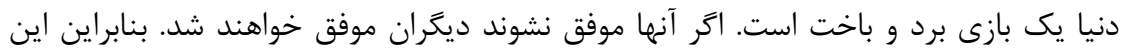

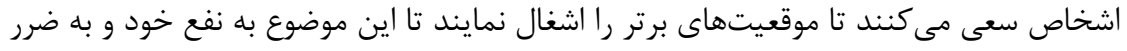

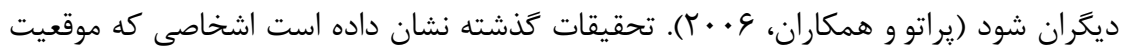

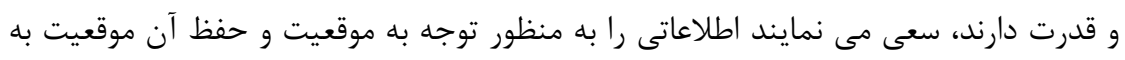

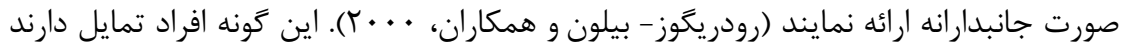

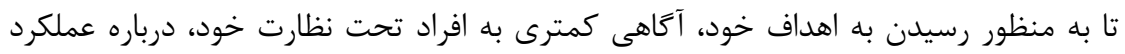

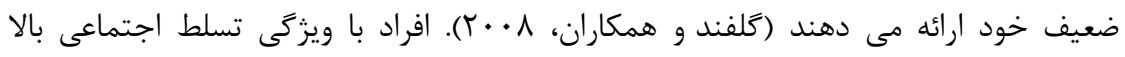

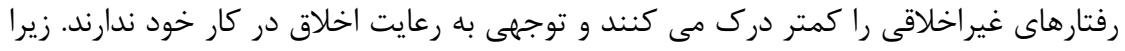

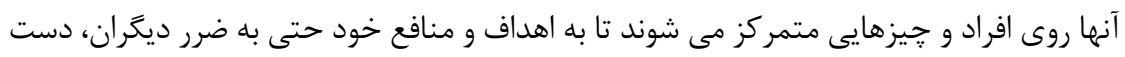

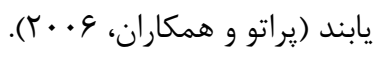

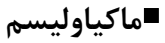

ماكياوليسم (يا فرصت طلبى) يك ويزگى شخصيتى است و عبارتست از ميزان نفوذ و سلطه

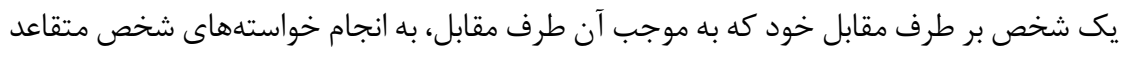

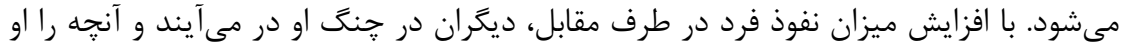

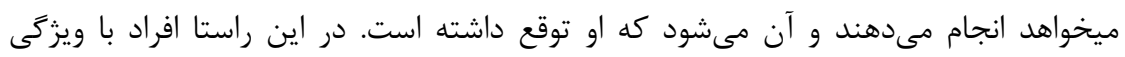

\footnotetext{
${ }^{1}$ opportunistic

${ }^{2}$ efficient

${ }^{3}$ Social Dominance

${ }^{4}$ Machiavellianism
} 
ماكياوليسم براى انجام وظيفه خود از افراد تحت سلطه خود براى رسيدن به هدف، به عنوان يك

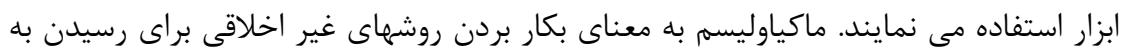

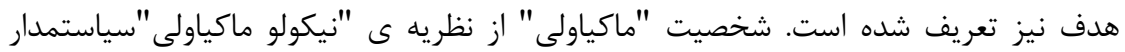
ايتاليايى قرن يانزدهم ميلادى اقتباس شده است و بر اساس دو ديد تاه عمده ى: "هدف، وسيله

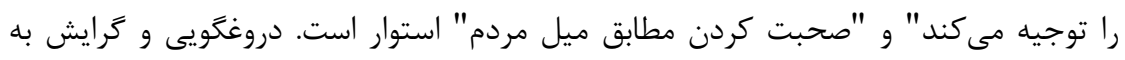

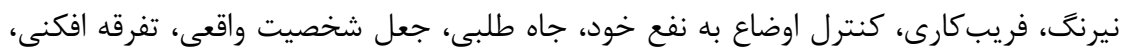

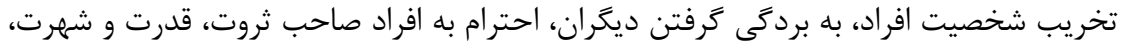

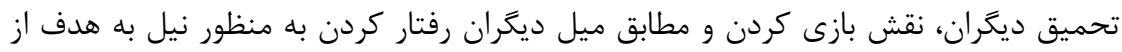

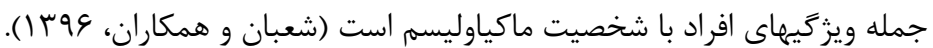

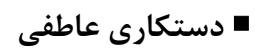

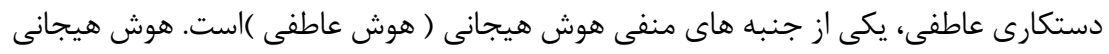

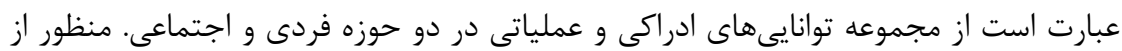
حوزه فردى شناخت و آكاهى از هيجانات خود است و حوزه اجتماعى يعنى آكاهى از از احساسات

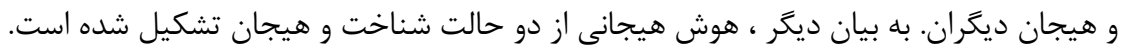

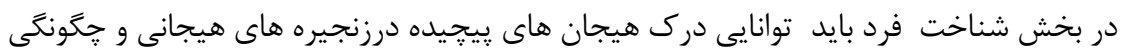

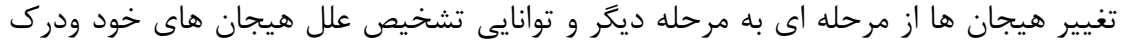

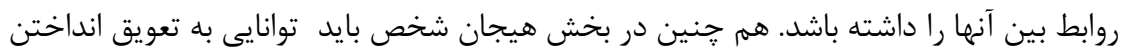

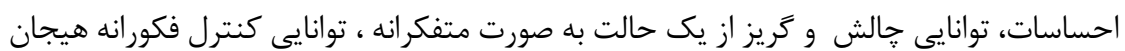

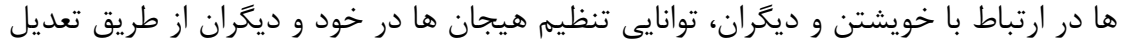

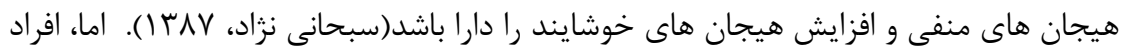

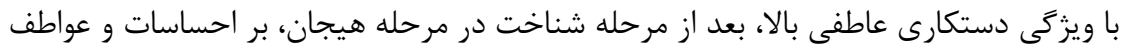

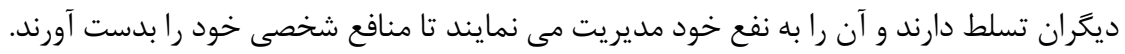

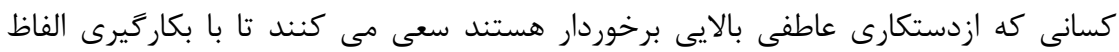

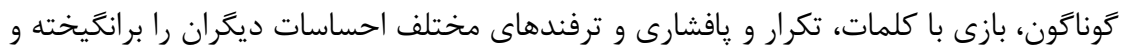

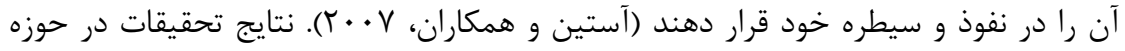

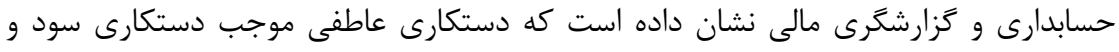

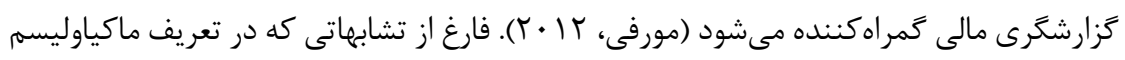

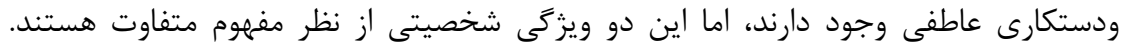

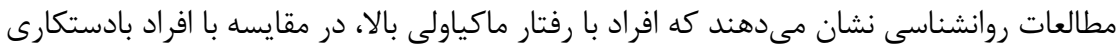

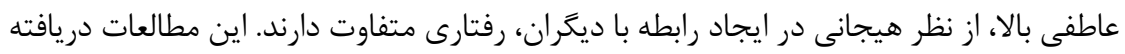


دov دكتر مرادزاده و همكاران، نقش متغيرهاى تسلط اجتماعى، ماكياوليسم و دستكارى عاطفى بر مديريت سود

اند كه ماكياوليسم رابطهاى منفى با همدلى دارد. هم جنين افراد با ويزگى ماكياوليسم بالا توانايى

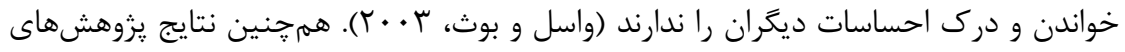

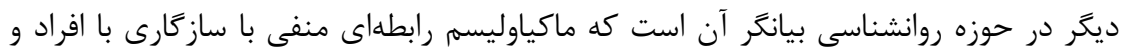

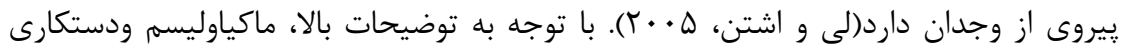

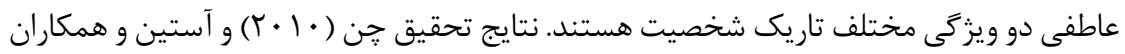

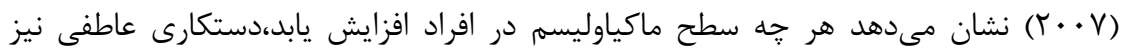

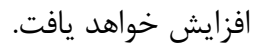

\section{ريشينه تحقيق}

روانشناسان تأثير هيجانات بر فرايند تصميمكيرى را از جنبهانهاى مختلف بر رسى نمودهاند.

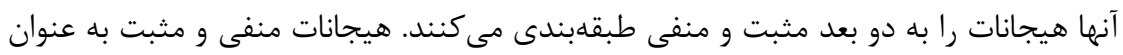

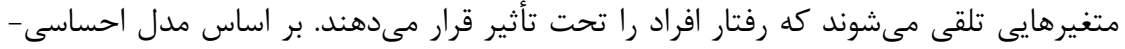
شناختى، نظريهى قضاوت اجتماعى عنوان مىنمايد كه احساسات و هيجانات مثبت به قضاوتهاي

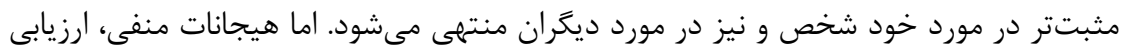

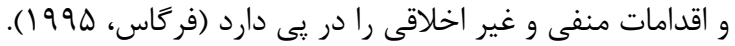

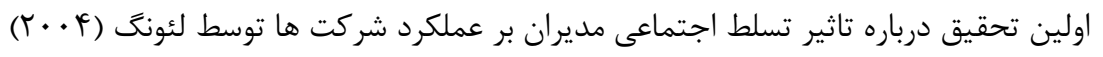

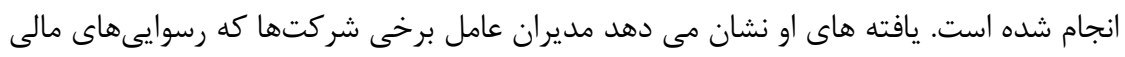

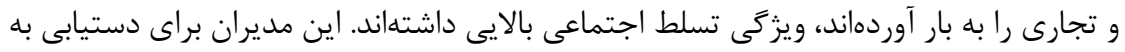

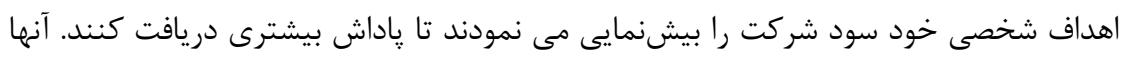

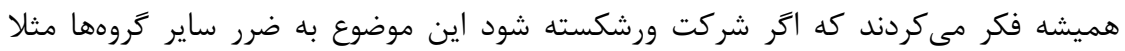

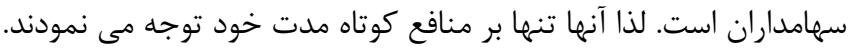

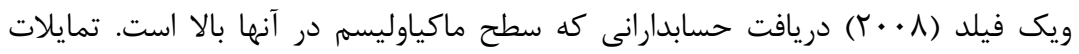

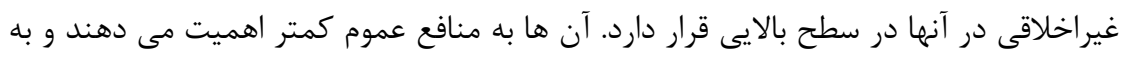

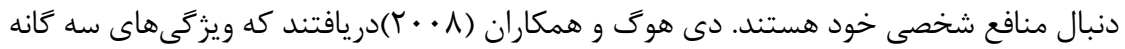

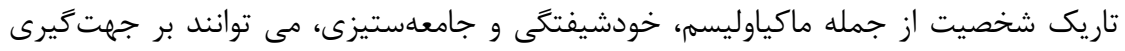

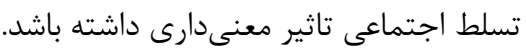

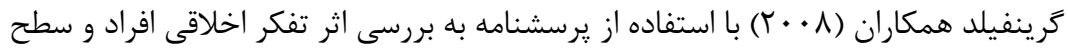

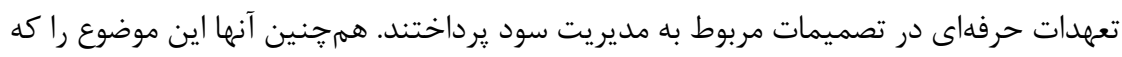

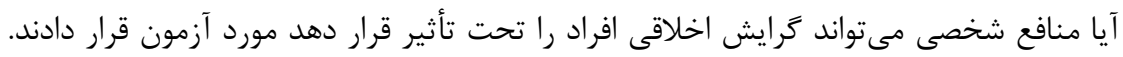

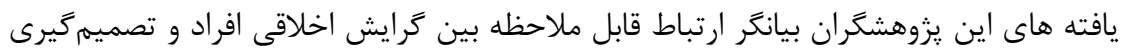


درباره بيشنمايى سود بود. همجنين افرادى كه تعهد حرفهاى بيشترى داشتند تمايل كمترى به مديريت سود داشتند.

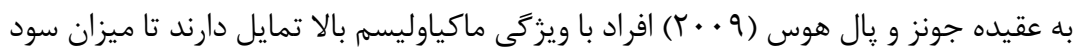
خود را كمتر از واقع كزارش نمايند.

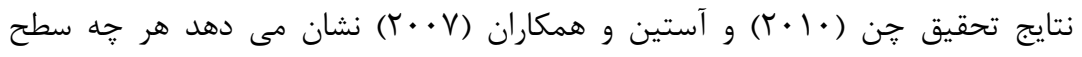
ماكياوليسم در افراد افزايش يابد،دستكارى عاطفى نيز افزايش خواهد إند يافت. هارتمن (• ( • (T) در يزوهش خود دريافتند در مواقعى كه مديريت واحدهاى تجارى از سوى جامعه براى تصميمگيرهاى مرتبط با مسئوليت اجتماعى شركت تحت فشار هستند، كنترلرها و حسابداران مديريت از سوى مديريت واحد تجارى، مجبور هستند تا با اعلام كسرى بودجه بر مرئ نتايج آن تصميمَّيرىها تاثير حذار باشند. در جنين مواقعى، ميزان ماكياوليسم در حسابداران

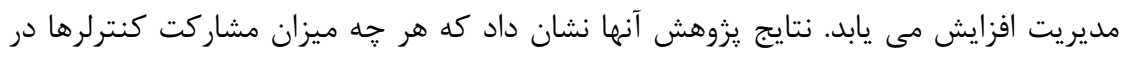

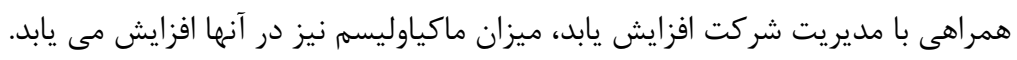

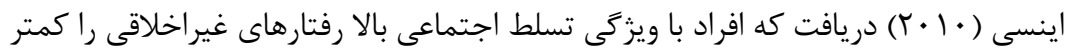

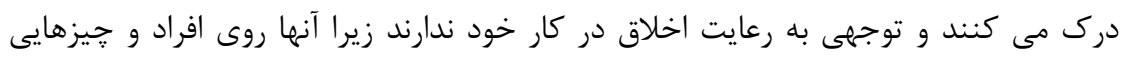

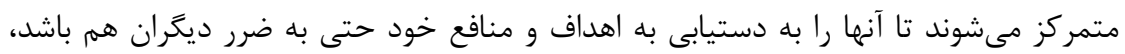
هدايت كنند.

شيفر و وانت (11 • ( ) در جين رابطهحى ميان رفتار ماكياوليسمى حسابرسان، در برخورد با

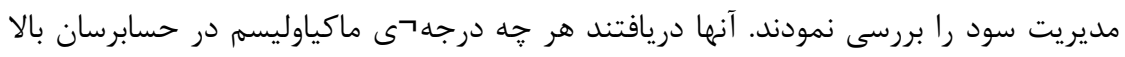

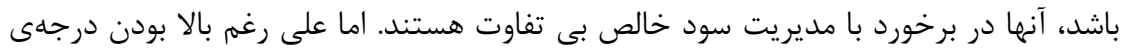
ماكياوليسم در ميان حسابرسان، اين بى تفاوتى در برخورد با مديريت سود عملياتى وجود ندارد.

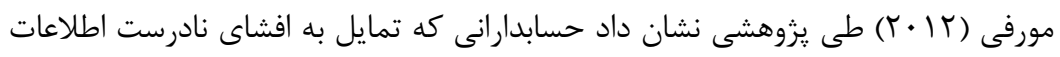
حسابدارى دارند، سطح ماكياوليسم ودستكارى عاطفى در آنها بالا است. اين دسته از حسابداران بابت افشاى نادرست اطلاعات نگرانى و يا احساس يشيمانى نيز ندارند. او ييشنههاد مى حكند كه

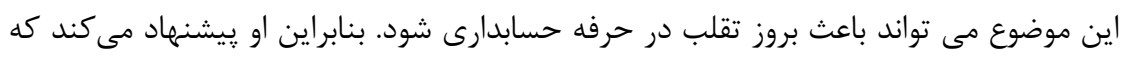
نهادهاى نظارت كننده بر حرفه حسابدارى بايد نظارت بيشترى بر حسابداران حرفهاى داشته باشد.

او هم جنين نشان داددستكارى عاطفى رابطهاى مستقيم با گزارشخرى مالى متقلبانه دارد.

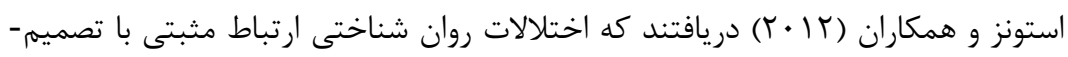
گيرى غيراخلاقى دارند. علاوه بر اين، دريافتند كه از بين ويزگگىهاى سه گانه تاريك شخصيت، اختلالات روانى مذكور با تسلط اجتماعى ارتباط دارند. 
دكتر مرادزاده و همكاران، نقش متغيرهاى تسلط اجتماعى، ماكياوليسم و دستكارى عاطفى بر مديريت سود وهب

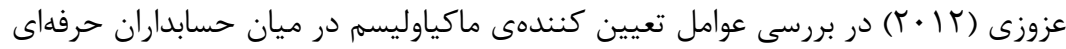

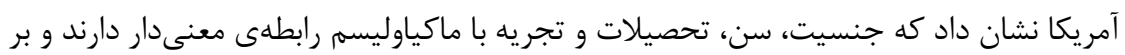
آن تاثير كذار هستند.

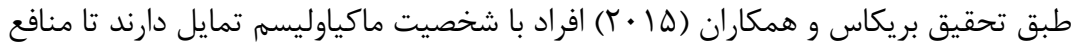

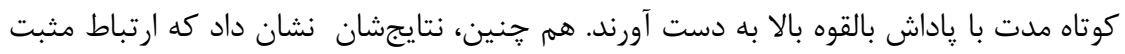

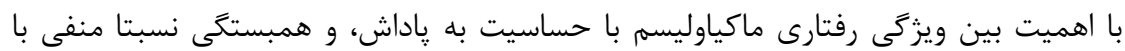
حساسيت به جريمه وجود دارد.

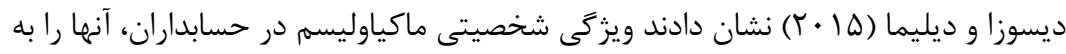

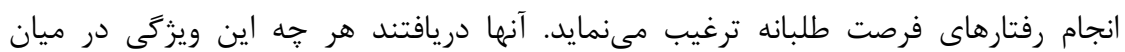

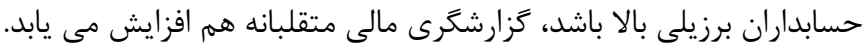

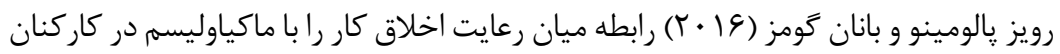

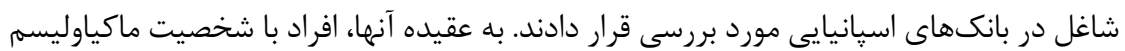
رفتارهاى غير محافظهكارانه و فرصتطلبانهاى را براى حداكثر سازى منافع شخصى خود انجام إنام

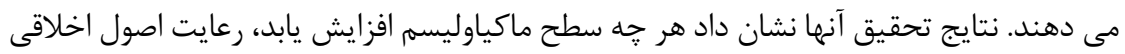
نيز كاهش مي يابد.

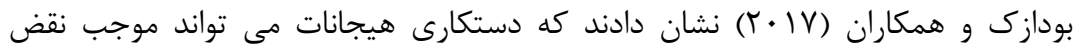

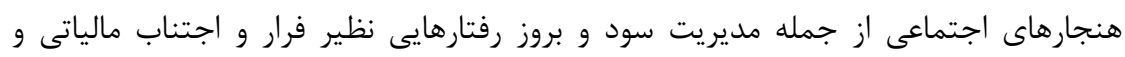
يولشويى شود. هام و همكاران (Y V (T) دريافتند كه امكان مديريت سود در شر كتهايى كه مديران آن فر آيند

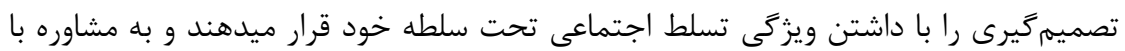
ديكران تمايل نشان نمى دهند.

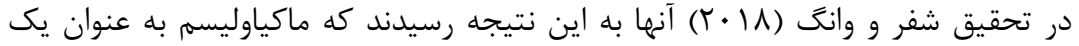
ويزگى تاريك شخصيت مىتواند بر تمايل به كزارش كمتر سود تاثير مستقيم داشته ياشد.

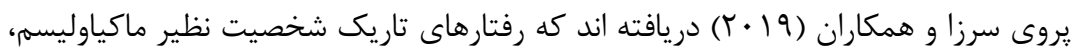
خودشيفتكى و جامعه ستيزى ارتباط معنى دارى با قانونكريزى دارد.

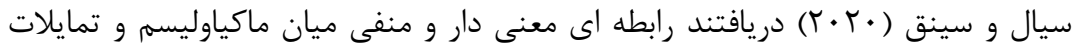

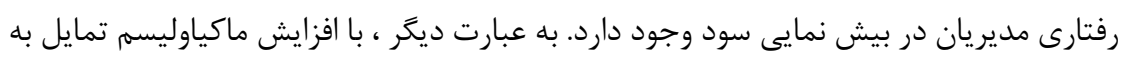

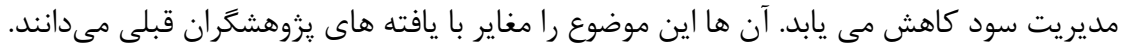




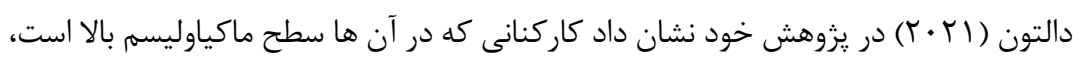

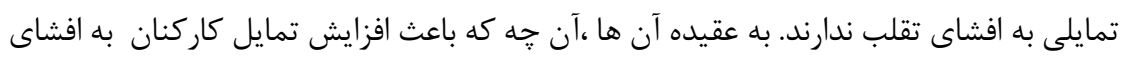

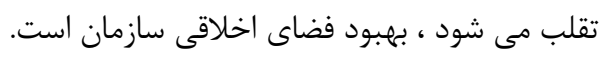

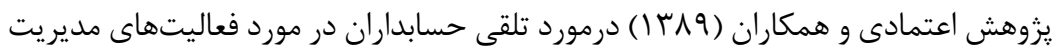

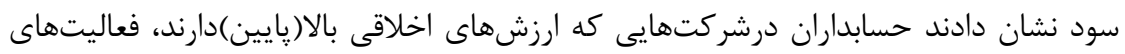

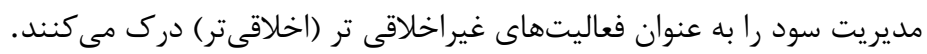

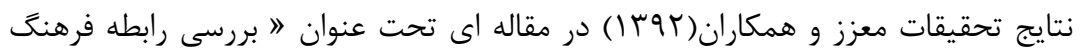

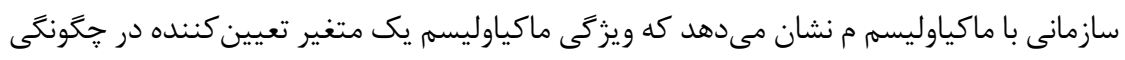
رفتار در محيط شغلى است.

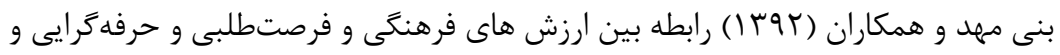

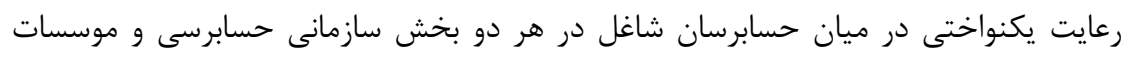

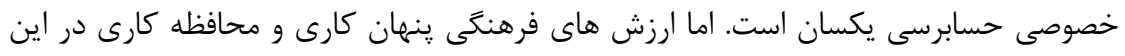

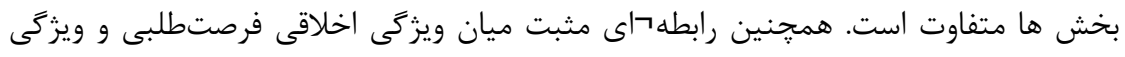

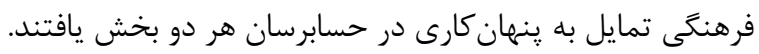

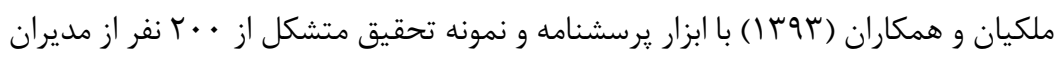

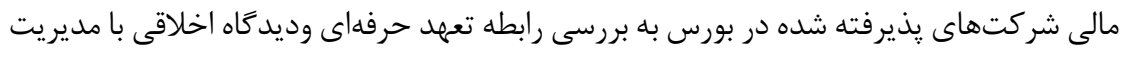

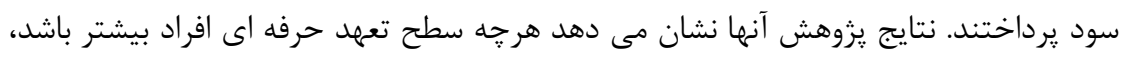
كمتر اقدام به مديريت سود مى نمايند.

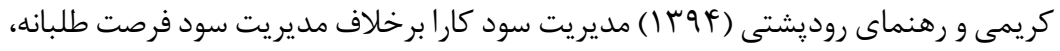

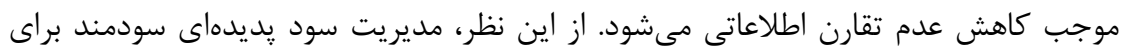

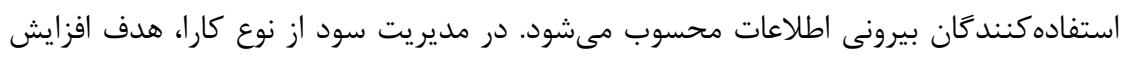

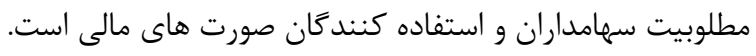

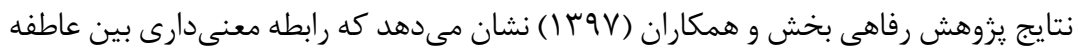

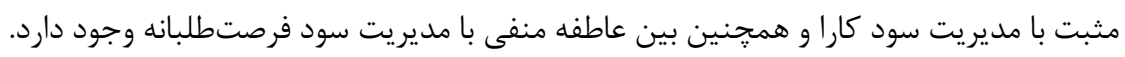

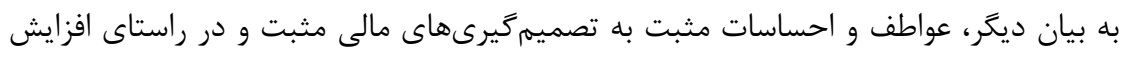

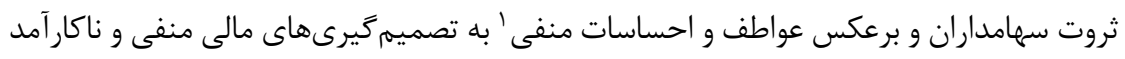
و در راستاى منافع شخصى مديريت منجر مىشودا.

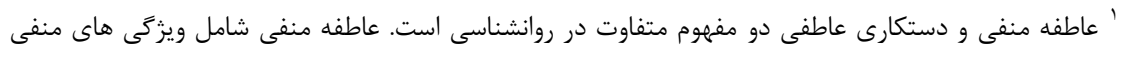

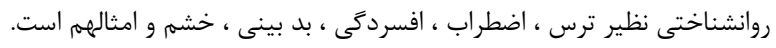


دكتر مرادزاده و همكاران، نقش متغيرهاى تسلط اجتماعى، ماكياوليسم و دستكارى عاطفى بر مديريت سود اجس

نتايج تحقيفات احمدى و همكاران (Y (I IV) نشان مى دهد كه مولفه هوش هيجانى تهيه كنند

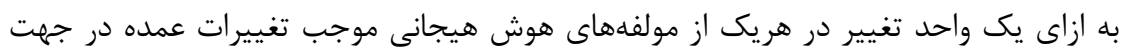

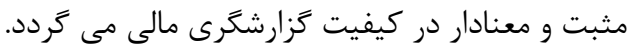

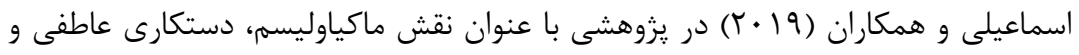

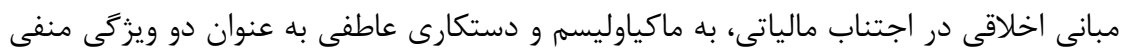

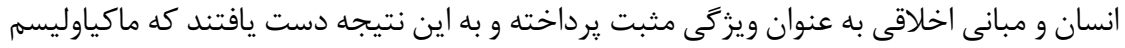

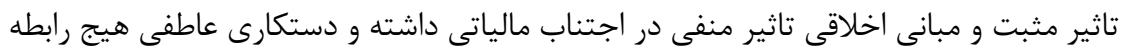
معنى دارى با يديده اجتناب مالياتى ندارد.

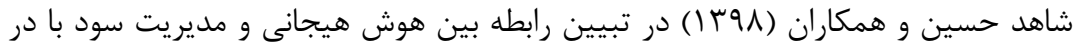

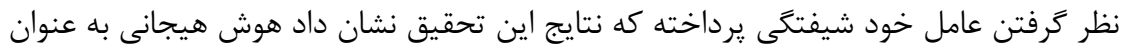

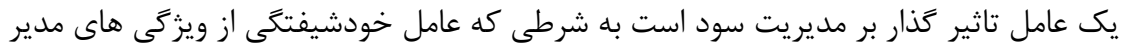

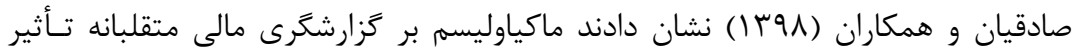

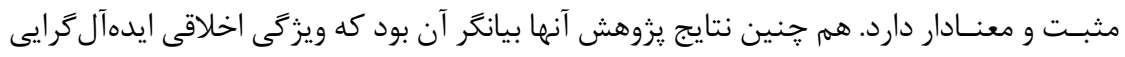

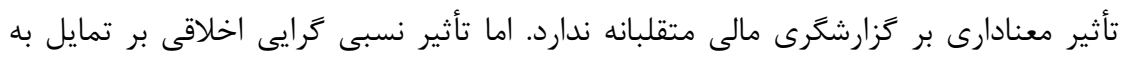

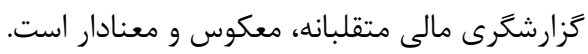

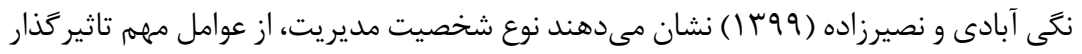

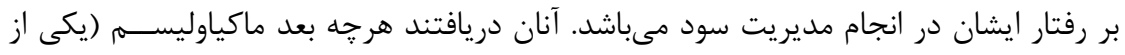

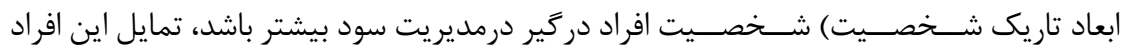
به مديريت سود تعهدى بيشتر مىشود و اين تمايل با وجود رهبرى اخلاقى در شركت در دريت كاسته مىشود. - مئر منصورزارع و همكاران (99 (1) در بررسى تاثير خودشيفتكى مدير ان بر مديريت سود، دريافتند

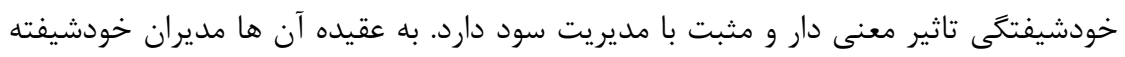

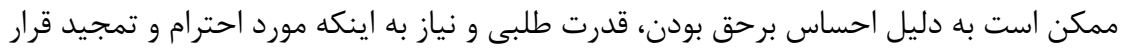

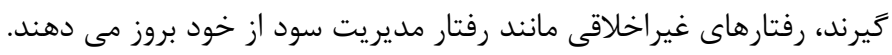

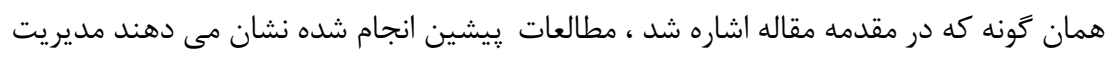

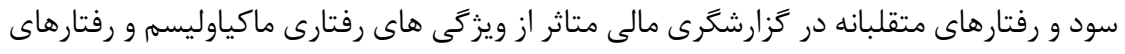

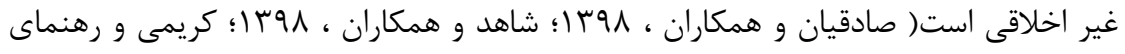

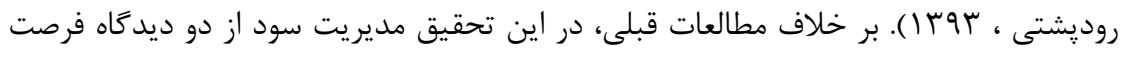


طلبانه و كارايى مورد بررسى قرار گرفته است. هم حنين متغير هاى تسلط اجتماعى و دستكارى

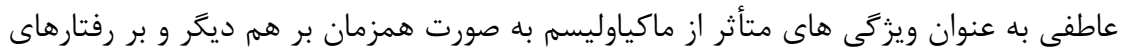

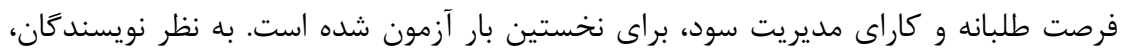

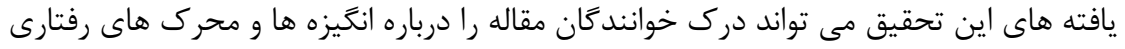

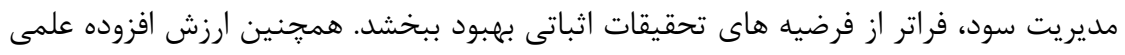

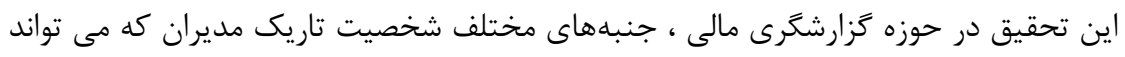

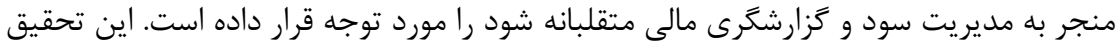

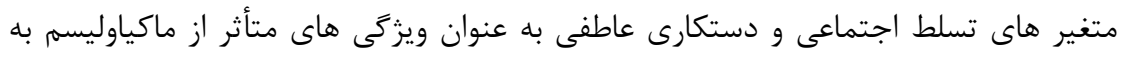

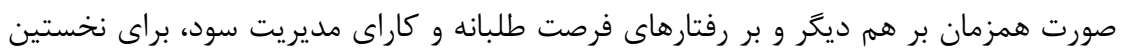

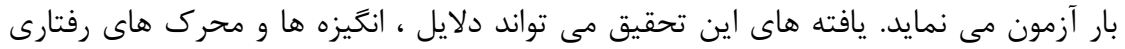

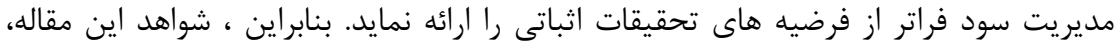

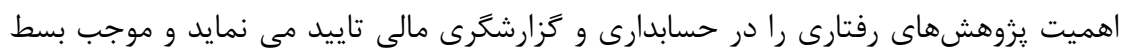

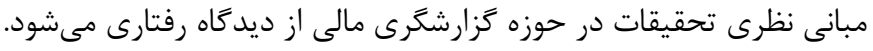

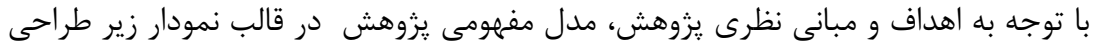

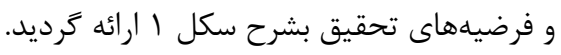

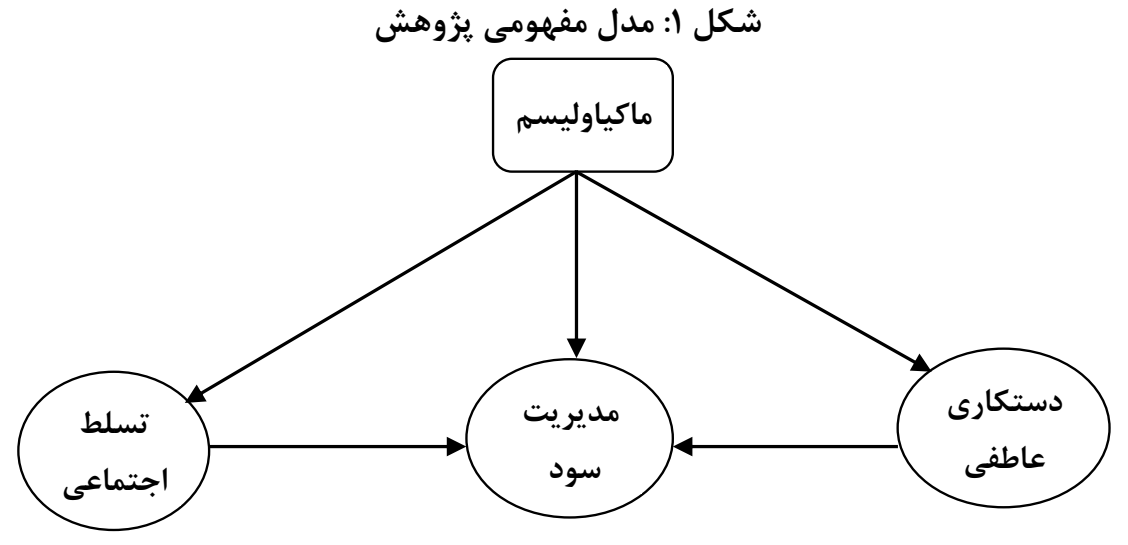

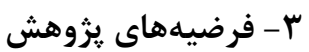

ماكياوليسم ودستكارى عاطفى دو ويزگى مختلف تاريك شخصيت هستند. نتايج تحقيق جن

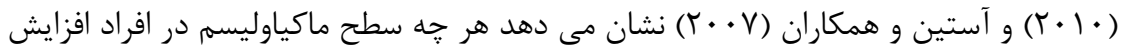

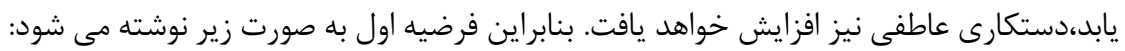
فرضيه اول: ماكياوليسم بردستكارى عاطفى تاثير مثبت و معنى دارى دارد. 
دكتر مرادزاده و همكاران، نقش متغيرهاى تسلط اجتماعى، ماكياوليسم و دستكارى عاطفى بر مديريت سود سجس

تحقيقات كذشته نشان داده است اشخاصى كه در موقعيت تسلط اجتماعى بالاترى هستند ،

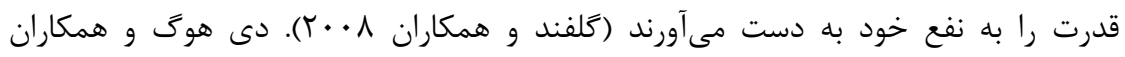

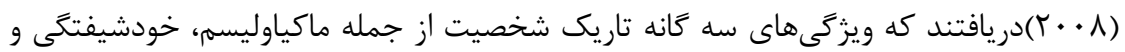

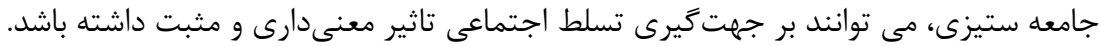

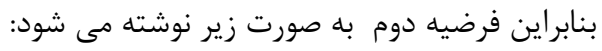

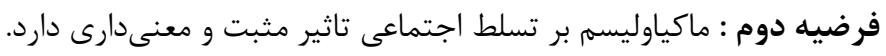
در توجيح فرضيدهاى سوم، جهارم، ششم و هفتم؛ ماكياوليسم ودستكارى عاطفى متغير هاى

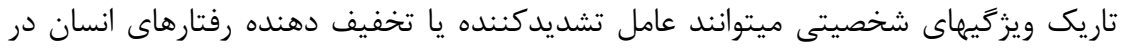

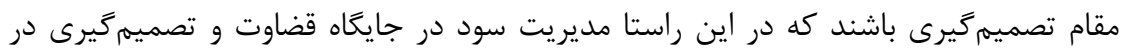

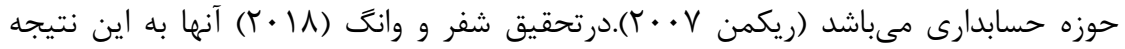

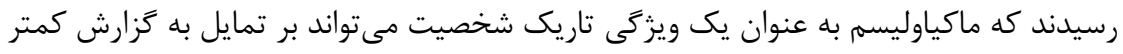

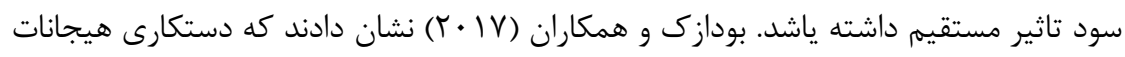

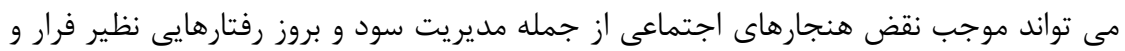

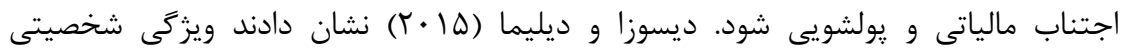

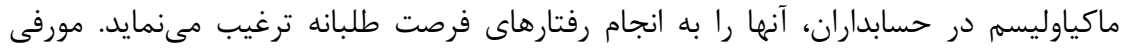

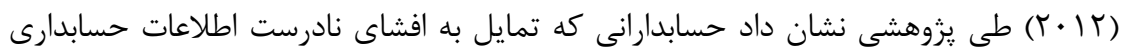

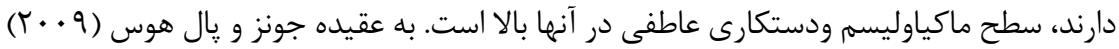

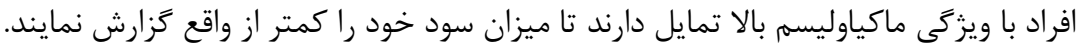

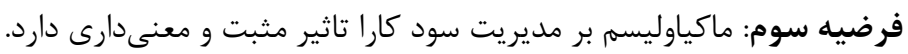
فرضيه جهارم:دستكارى عاطفى بر مديريت سود كارا تاثير مثبت و معنى دارى دارد. فرضيه ششم: ماكياوليسم بر مديريت سود فرصت طلبانه تاثير مثبت و معنى دارى دارد. فرضيه هفته:دستكارى عاطفى بر مديريت سود فرصت طلبانه تاثير مثبت و معنى دارى دارد.

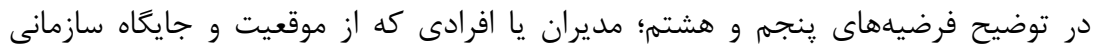

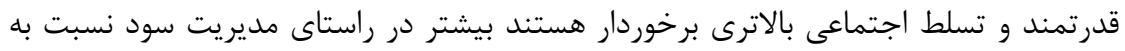
افراد و يا مديرانى كه از تسلط اجتماعى كمترى برخوردار مى باشند، بودهاند(فنَ و همكاران،

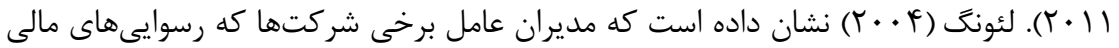

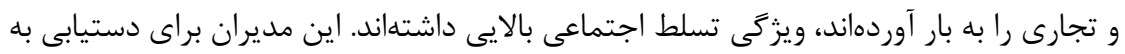
اهداف شخصى خود سود شركت را بيشنمايى مى نمودند تا پاداش بيشترى دريافت كنند. فرضيه ينجم: تسلط اجتماعى بر مديريت سود كارا تاثير مثبت و معنى دارى دارد. 
فرضيه هشتم: تسلط اجتماعى بر مديريت سود فرصت طلبانه تاثير مثبت و معنىدارى دارد.

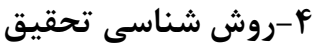

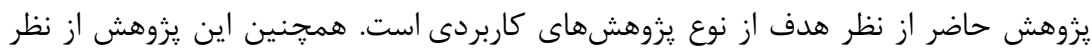

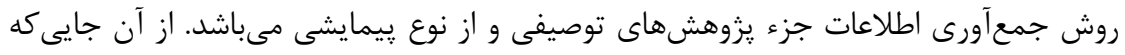

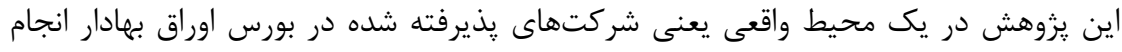

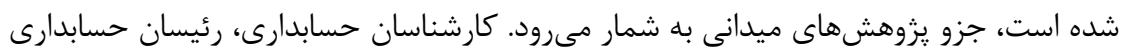

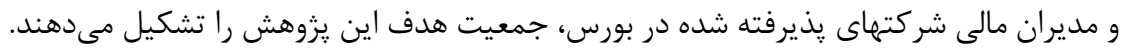

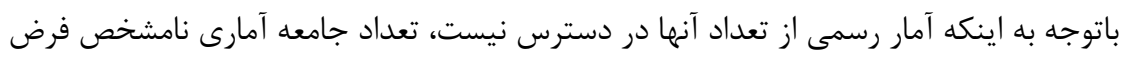

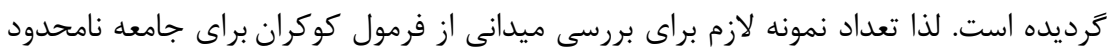
استفاده شده است. معادله فرمول ياد شده به شكل زير است:

$$
n=\frac{Z_{\frac{\alpha}{2}}^{2} p q}{d^{2}}
$$

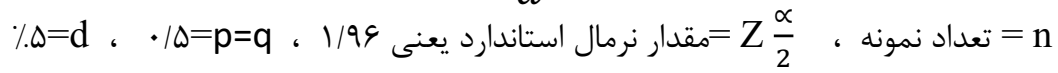

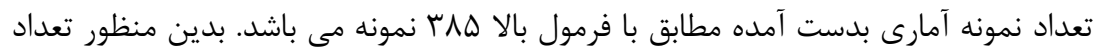

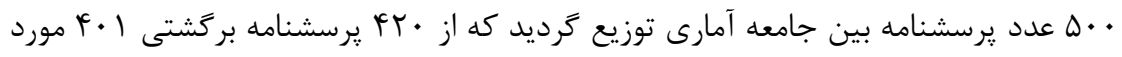

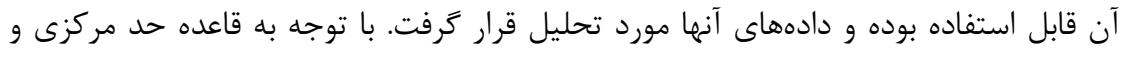

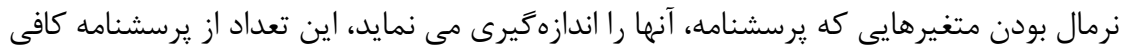

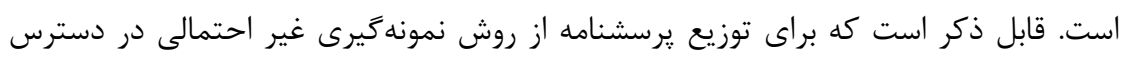
استفاده شده است.

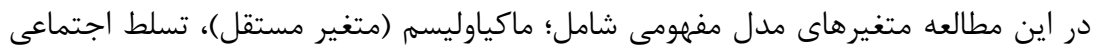

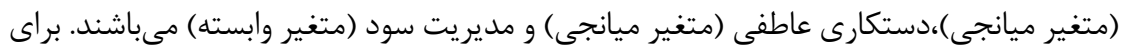

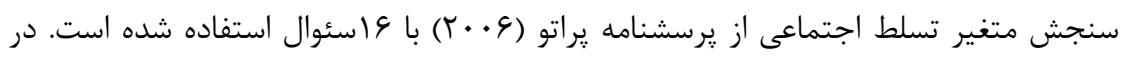

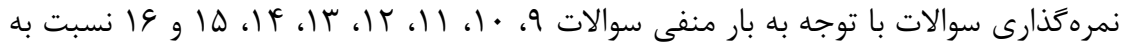

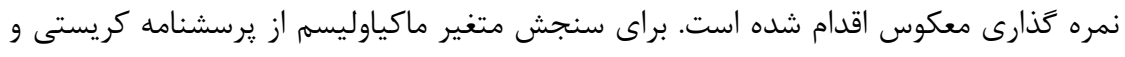

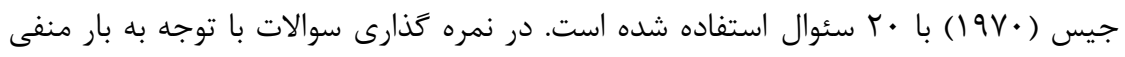

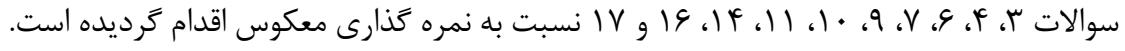

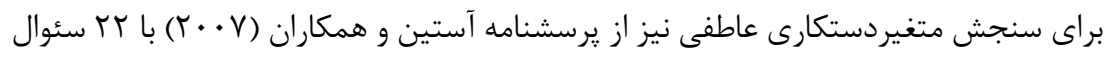

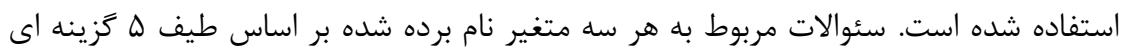


ليكرت از كاملاً مخالفم (1) تا كاملاً موافقم (ه) نمره كذارى شدهاند.

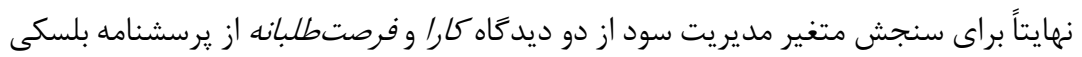

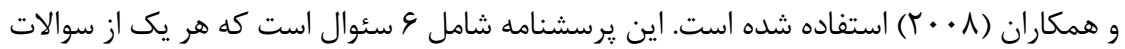

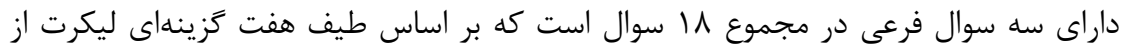

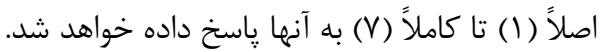

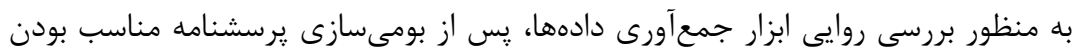

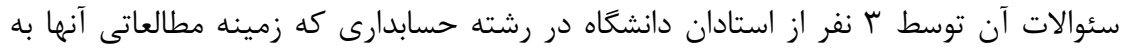

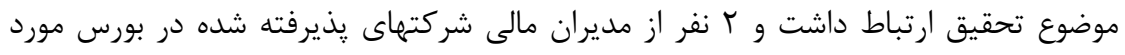

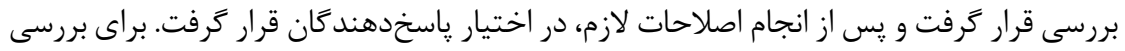

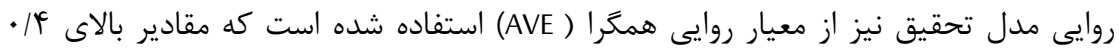

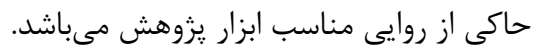

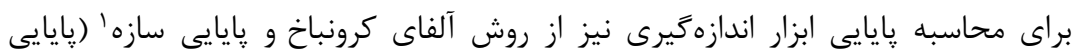
تركيبى) استفاده شده است. ضرايب آلفاى كرونباخ متغيرهاى تحقيق و ضريب دائ بايايى تركيبى

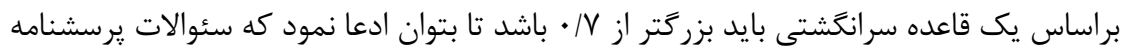

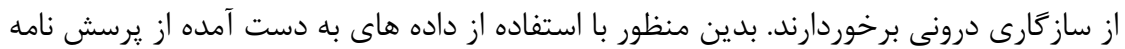

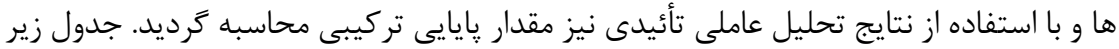
خلاصه نتايج بررسى روايى و بايايى را نشان مى دهد.

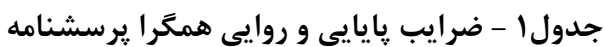

\begin{tabular}{|c|c|c|c|}
\hline AVE & پايايى تركيبى & آلفاى كرونباخ & 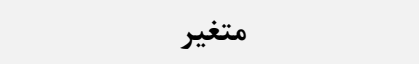 \\
\hline .1110 & $. / \mathrm{A} \mid \mathrm{T}$ & . /VTY & ماكياوليسم \\
\hline$\cdot / A Y \Lambda$ & - /ATS & $\cdot \mid V T I$ & دستكارى هيجانى \\
\hline$\cdot / V \Delta I$ & . IArr & $\cdot / \mathrm{VA}$. & تسلط اجتماعى \\
\hline$\cdot / V \Delta A$ &.$/ \Lambda \& Y$ &.$/ \mathrm{VqF}$ & مديريت سود از ديدگاه كارايى \\
\hline$\cdot / v 9$. &.$/ 1 \wedge 9$ & . MET & مديريت سود از ديدكاه فرصت طلبانه \\
\hline
\end{tabular}

در اين يزوهش، براى تحليل داده هاى جمعآورى شده از روش هاى آمار توصيفى و آمار

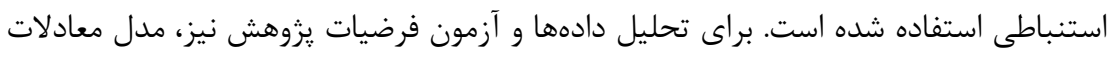

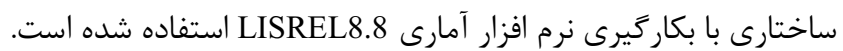

1 Construct Reliablity 


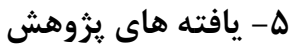

آمار توصيفى

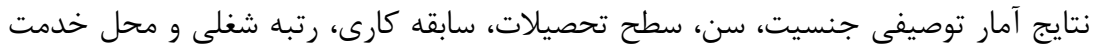

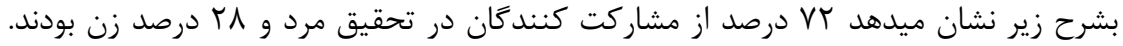

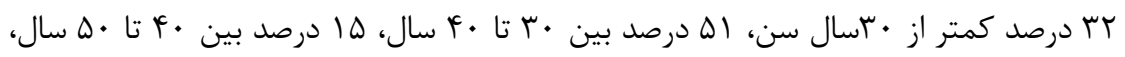

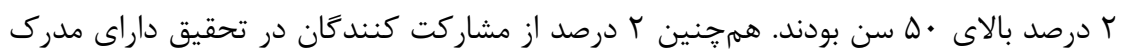

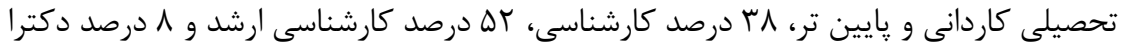

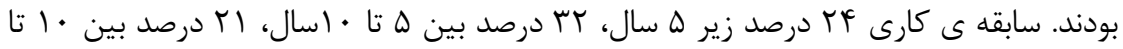

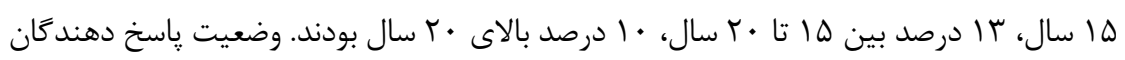

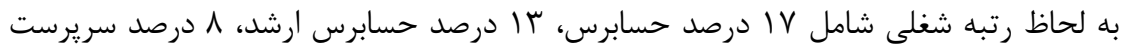

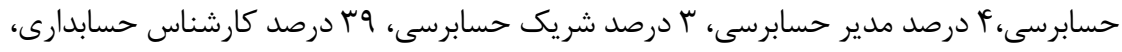

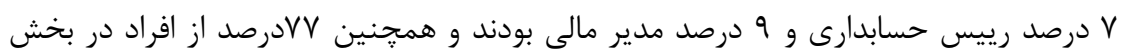
خصوصى و rا ب درصد از افراد در بخش دولتى مشغول بكار بودند.نتايج تحليل داده متغيرهاى

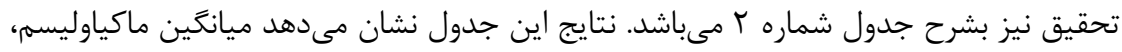

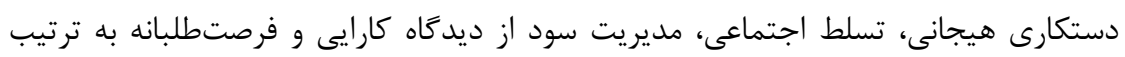

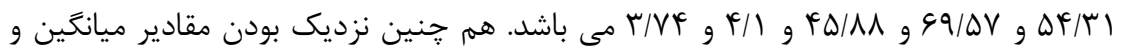

$$
\text { ميانه نشان دهنده نرمال بودن توزيع متغيرها است. }
$$

جدول r- نتايج تحليل متغيرها

\begin{tabular}{|c|c|c|c|c|c|}
\hline ديدكاه فرصت سولبانه & مديدياه كارايى سود از & اجتماعى & دسيجانى & ماكياوليسم & متغيرها \\
\hline$r / V F$ & $F / 1$ & $F \Delta / \Lambda \Lambda$ & $99 / \Delta V$ & $\Delta F / T$ & |ميانگين \\
\hline$r / V V$ & F/TT & fq & 99 & $\Delta F$ & |ميانه \\
\hline . 194 & $\cdot 19$ & G/V & $9 / 09$ & $9 / 4 \Lambda$ & انحراف معيار \\
\hline 1 & 1 & rI & rr & TV & حداقل \\
\hline $9 / \pi r$ & $g / F^{4}$ & बr & $1 \cdot r$ & $V F$ & حداكثر \\
\hline
\end{tabular}

س نتايج آزمون فرضيه ها

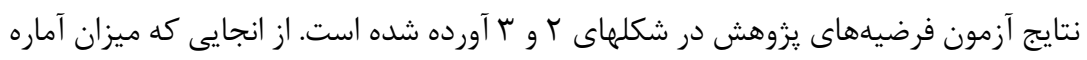

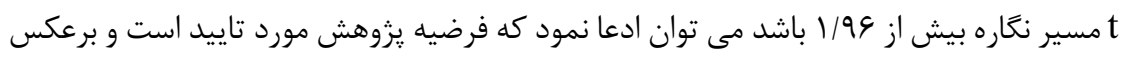


دكتر مرادزاده و همكاران، نقش متغيرهاى تسلط اجتماعى، ماكياوليسم و دستكارى عاطفى بر مديريت سود ل

اكر ميزان آماره t مسير نكاره كمتر از 19 19 باشد ؛ مى توان ادعا نمود كه فرضيه يزوهش مورد

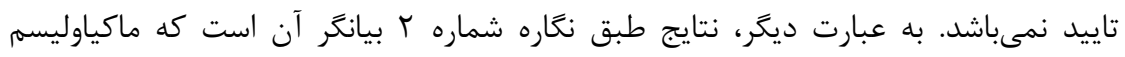

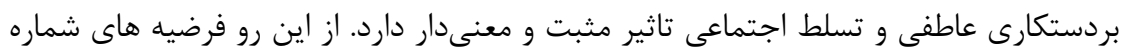

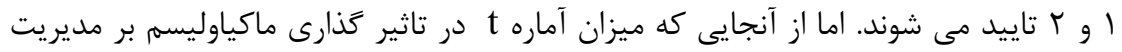

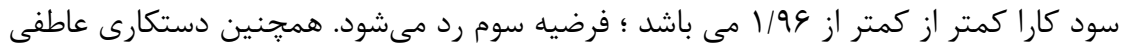

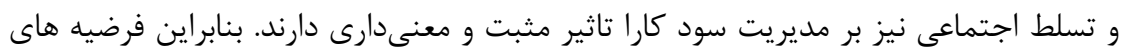

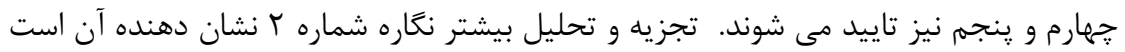

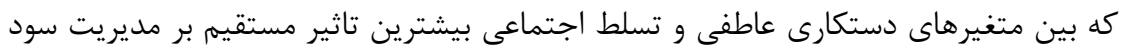

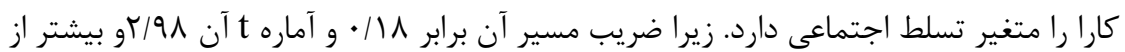
ضريب مسير متغيردستكارى عاطفى است. از طرف ديخر بررسى مسيرهاى غيرمستقيم حاكى از

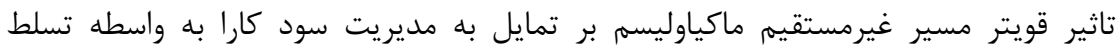

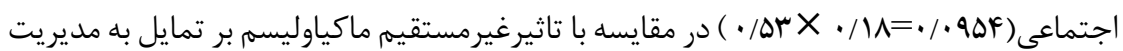
سود كارا به واسطه دستكارى عاطفى (

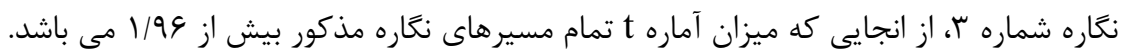

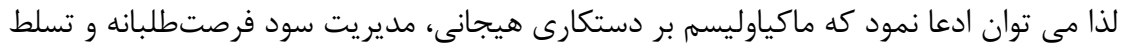

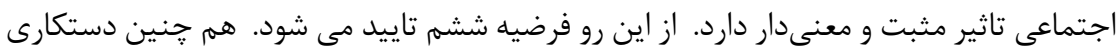

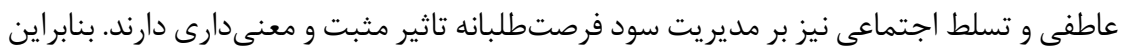

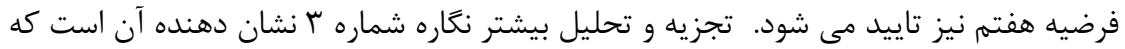
بين متغيرهاى ماكياوليسم،دستكارى عاطفى و تسلط اجتماعى بيشترين تاثير مستقيم بر مديريت

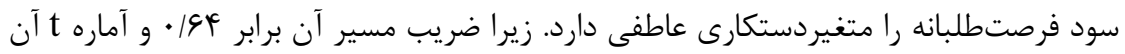

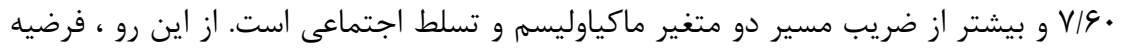

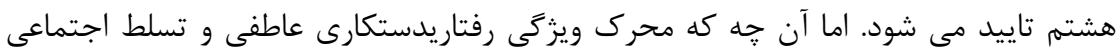

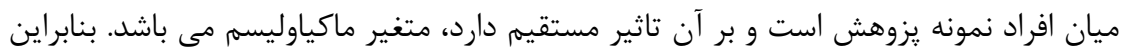

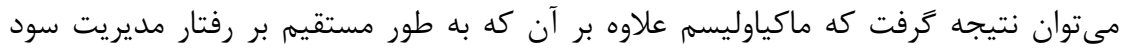

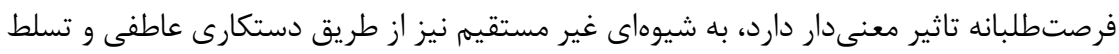

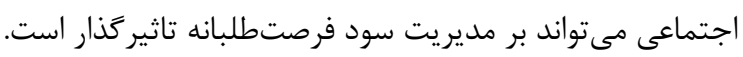

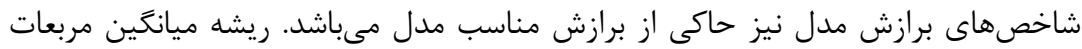

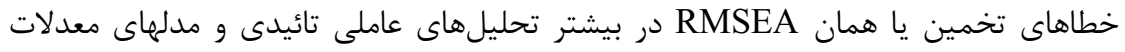

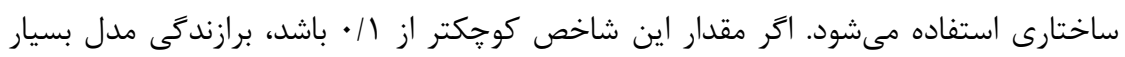




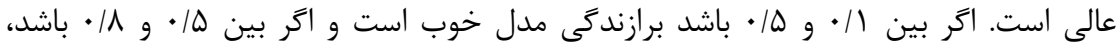

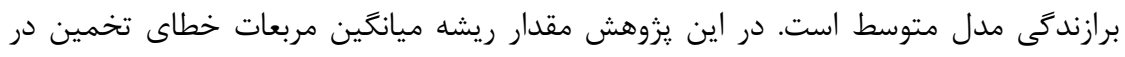

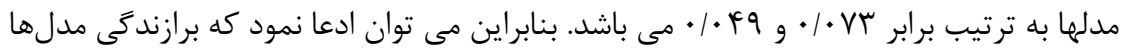
كوجيكتر از / / • و در سطح عالى است.

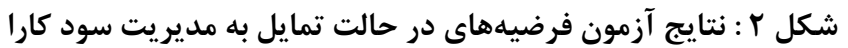

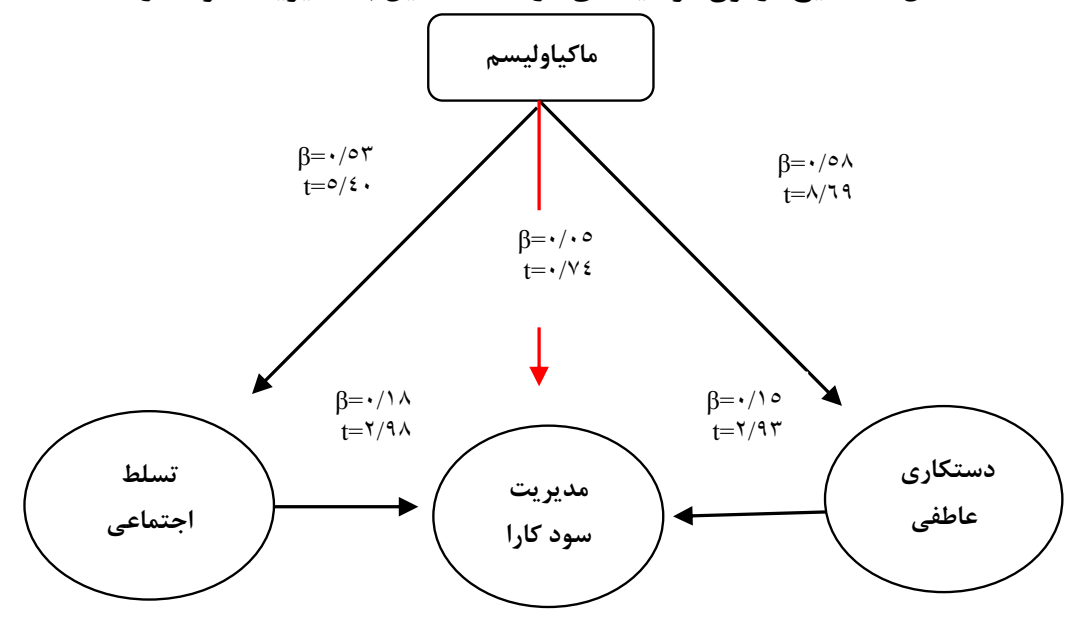

Chi-Square $=\mid \vee \uparrow / q \uparrow \quad$ df $=\Delta q \quad$ P-value $=\bullet / \cdots \quad$ RMSEA $=\bullet / \vee r$

شكل ץ : نتايج آزمون فرضيههاى در حالت تمايل به مديريت سود فرصت طلبانه

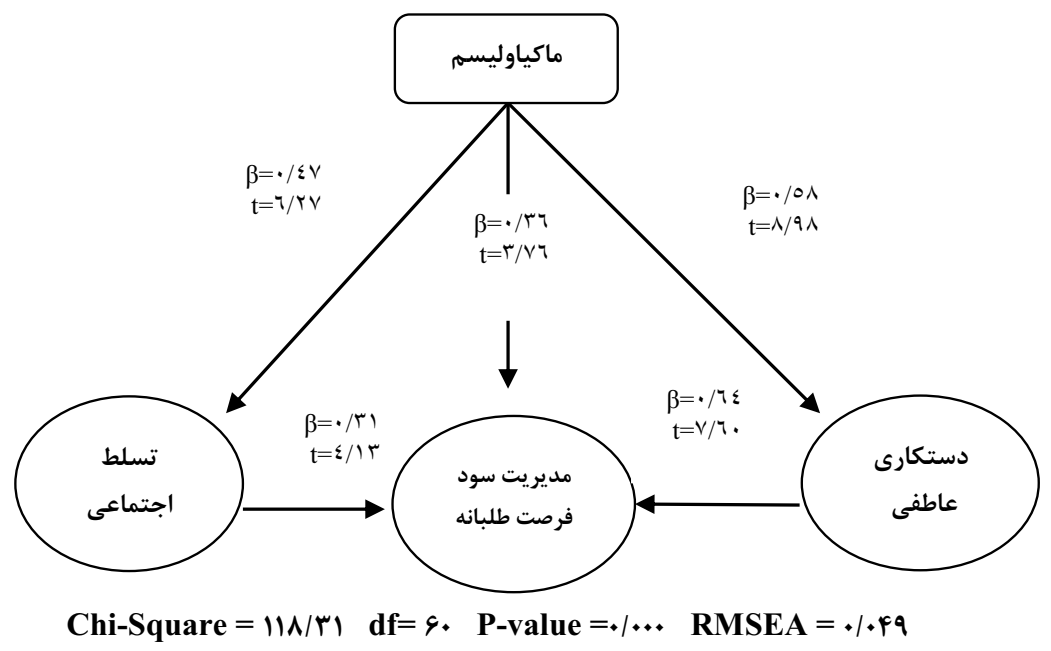


دكتر مرادزاده و همكاران، نقش متغيرهاى تسلط اجتماعى، ماكياوليسم و دستكارى عاطفى بر مديريت سود وجس

جدول شماره ஈ⿰: نتايج برازش معادلات ساختارى

\begin{tabular}{|c|c|c|c|c|}
\hline \multirow[b]{2}{*}{ وضعيت برازش } & \multirow[b]{2}{*}{ مقادير توصيه شده } & \multicolumn{2}{|c|}{ مقادير محاسبه شده شاخص ها } & \multirow[b]{2}{*}{ شاخص هاى برازش الگوى } \\
\hline & & مدل فرصت & مدل كارا & \\
\hline- & - & $|1 / / r|$ & $\mid V F / g F$ & Chi Square \\
\hline- & - & 4. & 4. & Df \\
\hline قابل قبول & Chi Square/Df $\leq 3$ & $1 / 9 \vee 11$ & r/99.. & Chi Square/Df \\
\hline قابل قبول & RMSEA $\leq 0.08$ & $\cdot 1 \cdot 4 q$ & $\cdot / \cdot v r$ & RMSEA \\
\hline
\end{tabular}

\begin{tabular}{|c|c|c|c|}
\hline \multicolumn{4}{|c|}{ جدول شماره f: نتايج آزمون فرضيه هاى يزوهش } \\
\hline آزتيجه & 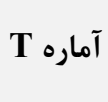 & ضريب & 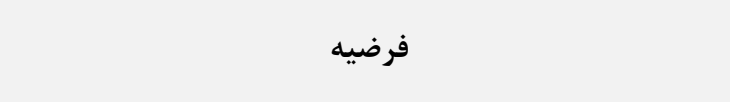 \\
\hline \multirow{2}{*}{ 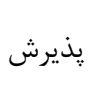 } & $1 / 99$ & $\cdot 10 \Lambda$ & تاثير ماكياوليسم بردستكارى عاطفى در مديريت سود كارا \\
\hline & N/91 & $\cdot / \Delta V$ & تاثير ماكياوليسم بردستكارى عاطفى در مديريت سود فرصت طلبانه \\
\hline \multirow{2}{*}{ يذيرش } & $\Delta / \mathcal{F}$. & $\cdot \mid \Delta \mu$ & تاثير ماكياوليسم برتسلط اجتماعى در مديريت سود كارا \\
\hline & G/TV & $\cdot / 4 V$ & تاثيرماكياوليسم برتسلط اجتماعى در مديريت سودفرصت طلبانه \\
\hline رد & $\cdot / V^{F}$ & $\cdot 1 \cdot \Delta$ & تاثير ماكياوليسم بر مديريت سود كارا \\
\hline 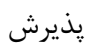 & $r / 9 \mu$ & 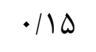 & تاثيردستكارى عاطفى بر مديريت سود كارا \\
\hline 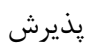 & $r / 9 \Lambda$ & $\cdot / 11$ & تاثير تسلط اجتماعى بر مديريت سود كارا \\
\hline 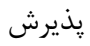 & T/VG & 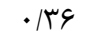 & تاثير بر ماكياوليسم مديريت سود فرصت طلبانه \\
\hline 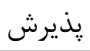 & $\mathrm{V} / 9$. & $\cdot \mid 94$ & تاثيردستكارى عاطفى بر مديريت سود فرصت طلبانه \\
\hline 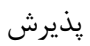 & $f / 1 r$ & $\cdot / \mu$ & تاثير تسلط اجتماعى بر مديريت سود فرصت طلبانه \\
\hline
\end{tabular}

\section{9- نتيجه}

اين تحقيق به عنوان يك تحقيق رفتارى، تاثير متغيرهاى تسلط اجتماعى، ماكياوليسم و

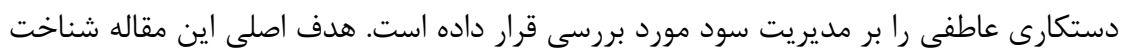
سطح تسلط اجتماعى، ماكياوليسم و جنبه منفى هوش هيجانى يعنى دستكارى عاطفى در ميان

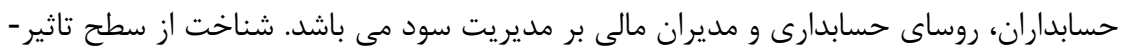

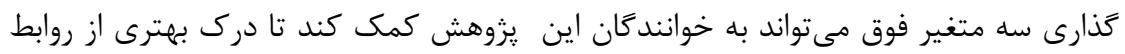

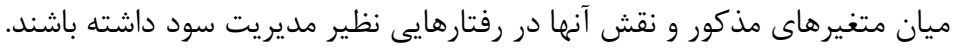


نتايج اين يزوهش نشان مىدهد كه انگَيزه مديريت در مديريت سود، متاثر از ويزگىهاى

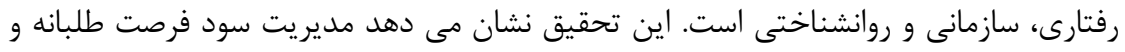

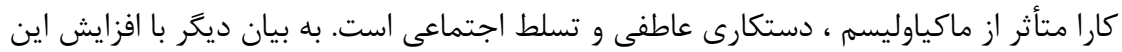

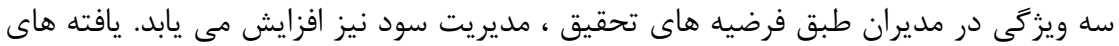

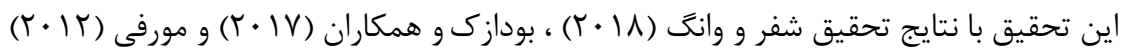

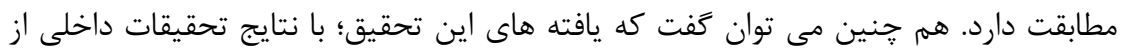

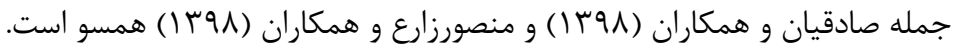

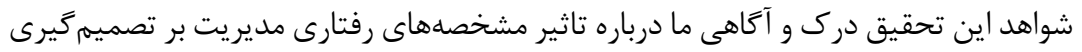

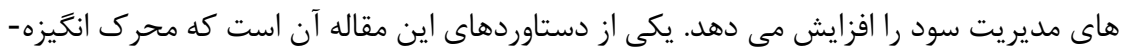

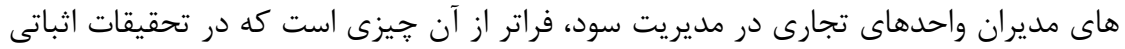

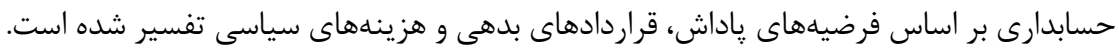

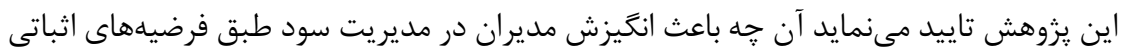
حسابدارى مىشود، عوامل روانشناختى، رفتارى و اجتماعى است. از اين رو، به عقيده نويسندكان

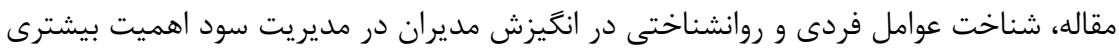

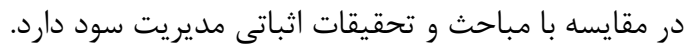

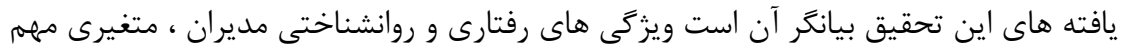

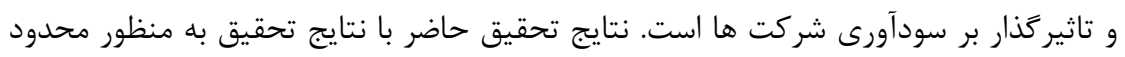

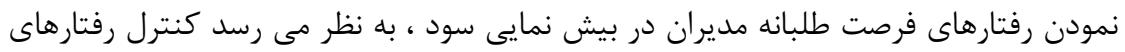

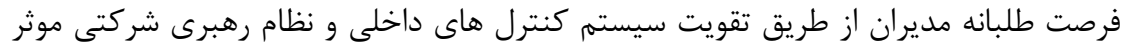

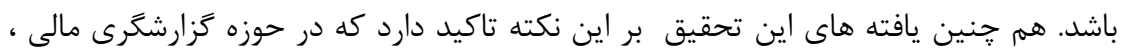

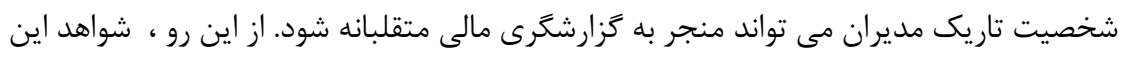

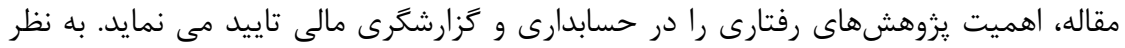

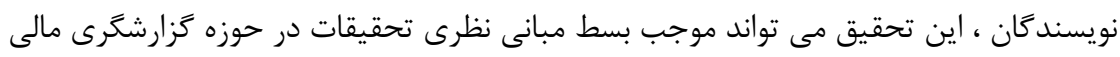

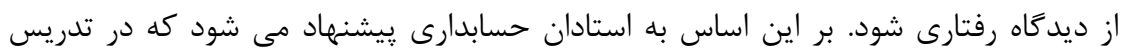

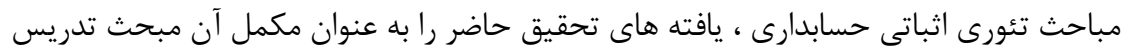

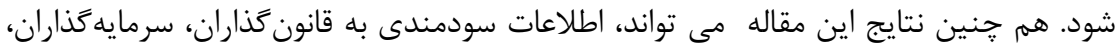

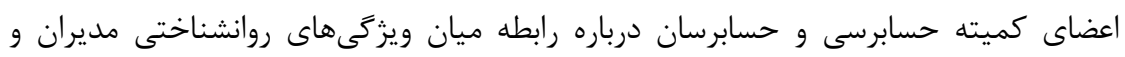

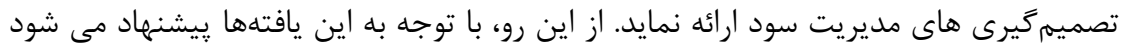

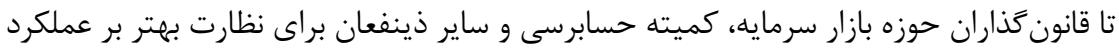


دكتر مرادزاده و همكاران، نقش متغيرهاى تسلط اجتماعى، ماكياوليسم و دستكارى عاطفى بر مديريت سود

مديريت، در بكار گيرى مديران، سلامت روانشناختى آنها را مبنايى براى ارزيابى قضاوت و تصميم-

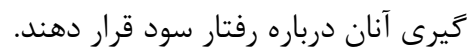

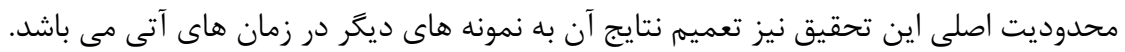

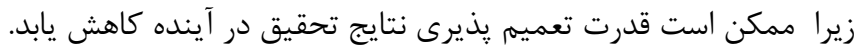

V- Vقدير و تشكرو ملاحظات اخلاقى اين يزوهش در طى فرايند رساله دكترى در رشته حسابدارى انجام كرفته است. نويسندكان مقاله بر خود واجب مى دانند از همكارى و مساعدت تمامى عزيزانى كه در اين طرح ماند را را يارى نموده اند، سياسگزارى نمايند.

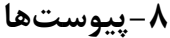

سوالات مرتبط با تسلط اجتماعى : لطفاً ميزان دقيق موافقت يا عدم موافقت خود را با با هر تويه باعل با علامت ضربدر مشخص نمائيد.

\begin{tabular}{|c|c|c|c|c|c|c|}
\hline \multicolumn{5}{|c|}{ 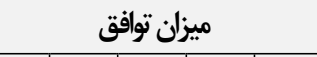 } & \multirow{3}{*}{ كويه ها } & \multirow{3}{*}{$\stackrel{\hat{9}}{9}$} \\
\hline$\Delta$ & $F$ & $r$ & $r$ & 1 & & \\
\hline 学 & $\frac{9}{: \frac{9}{8}}$ & $\begin{array}{l}\frac{3}{9} \\
\frac{3}{2} \\
2\end{array}$ & 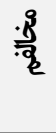 & . $\frac{h}{3}$ & & \\
\hline & & & & & |برخى گروههاى مردمى نسبت به كروههاى ديخر دون يايهترند. & .1 \\
\hline & & & & & |بريخر كروه دستيابى به آنجه مى خواهيد، كاهى ضرورى است از زور عليه &.$r$ \\
\hline & & & & & |مَروهاى ديخر داشته باشند. & $r$ \\
\hline & & & & & |براى بِيشرفت در زندگَى، كاهى لازم است روى كروههاى ديخر & .4 \\
\hline & & & & & |مى داشتر برخى كروهها جاى خود را عوض نمى كردند، مشكلات كمترى & 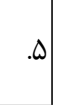 \\
\hline & & & & & |بايين قرار دارند. & .8 \\
\hline & & & & & | كروههاى دونيايه بايد در جاى خودشان باقى بمانند. &.$v$ \\
\hline & & & & & | كَاهى كروهها ديكر بايد در جاى خودشان حفظ شوند. & .1 \\
\hline & & & & & |خوب مى شد كه كروهها مساوى باشند. & .9 \\
\hline
\end{tabular}


دو فصلنامه حسابدارى ارزشى و رفتارى، سال ينجم، شماره دهم، پإييز و زمستان و9"1

\begin{tabular}{|c|c|c|c|c|c|c|}
\hline \multicolumn{5}{|c|}{ 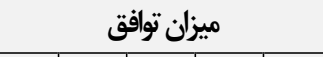 } & \multirow{3}{*}{ كويلها } & \multirow{3}{*}{$\hat{\mathfrak{9}}$} \\
\hline$\Delta$ & f & $r$ & $r$ & 1 & & \\
\hline 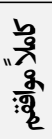 & $\frac{9}{19}$ & $\begin{array}{l}\text { 济 } \\
3 \\
\frac{3}{2}\end{array}$ & 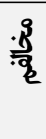 & 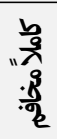 & & \\
\hline & & & & & |تساوى گروهى بايد ايدهآل ما باشد. & $.1 \cdot$ \\
\hline & & & & & همدٔ گروهها بايد شانس مساوى براى زندگى داشته باشند. & .11 \\
\hline & & & & & |بايد هر كارى از دستمان برمى آيد بكنيمم تا گروههاى مختلف از & $.1 \%$ \\
\hline & & & & & |با افزايش تساوى اجتماعى & $.1 \%$ \\
\hline & & & & & |كمترى مى باشت مردم با مساوات بيشترى برخورد مىكرديم، مشكلات & .14 \\
\hline & & & & & |بايد سعى كنيم در آمدها حتى الامكان برابر باشند. & .10 \\
\hline & & & & & هيجز گروهى بلتنههايى نبايد در جامعه تسلط داشته باشد. & .19 \\
\hline
\end{tabular}

سوالات مرتبط با ماكياوليسم : لطفاً ميزان دقيق موافقت يا عدم موافقت خود را با هر گويه با علامت ضربدر مشخص فرمائيد.

\begin{tabular}{|c|c|c|c|c|c|c|}
\hline \multicolumn{5}{|c|}{ ميزان توافق } & \multirow[b]{3}{*}{ كويه ها } & \multirow[b]{3}{*}{.$\hat{9}$} \\
\hline$\Delta$ & 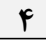 & $r$ & $r$ & 1 & & \\
\hline 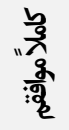 & $\frac{\mathscr{g}}{\mathfrak{S}_{2}}$ & 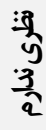 & 象 & 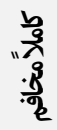 & & \\
\hline & & & & & 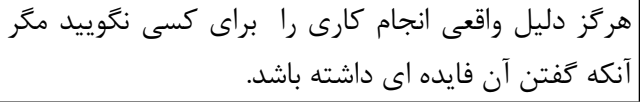 & .1 \\
\hline & & & & & به شنيدن آن دارند. بهن راه با مردم، كفتن آن جيزى است كه تمايل &.$r$ \\
\hline & & & & & 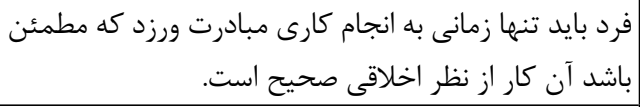 &.$r$ \\
\hline & & & & & اكثر مردم اساساً خوب و مهربان هستند. & .1 \\
\hline & & & & & 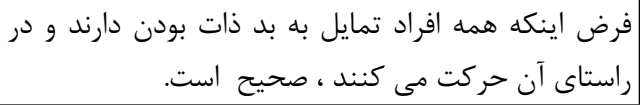 &.$\Delta$ \\
\hline & & & & & در همؤ موارد بهترين خط مشى ، صداقت است. & .9 \\
\hline
\end{tabular}


دكتر مرادزاده و همكاران، نقش متغيرهاى تسلط اجتماعى، ماكياوليسم و دستكارى عاطفى بر مديريت سود سVس

\begin{tabular}{|c|c|c|c|c|c|c|}
\hline \multicolumn{5}{|c|}{ 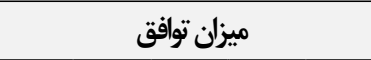 } & \multirow[b]{3}{*}{ تويه ها } & \multirow{3}{*}{$\stackrel{\grave{9}}{\hat{9}}$} \\
\hline$\Delta$ & F & $r$ & $r$ & 1 & & \\
\hline$\frac{b}{\frac{b}{\hbar}}$ & $\frac{g}{9}$ & $\begin{array}{l}: 9 \\
\frac{3}{2} \\
\frac{3}{2}\end{array}$ & .3 & 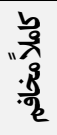 & & \\
\hline & & & & & هيج عذرى براى دروغ كفتن به ديخران پذيرفته نيست. &.$\vee$ \\
\hline & & & & & 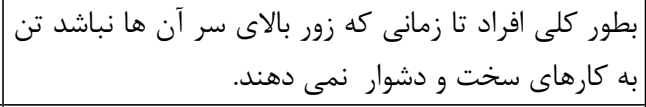 &.$\wedge$ \\
\hline & & & & & |ستى هم رفته فروتنى و صداقت بهتر از مهم بودن و رياكارى & .9 \\
\hline & & & & & 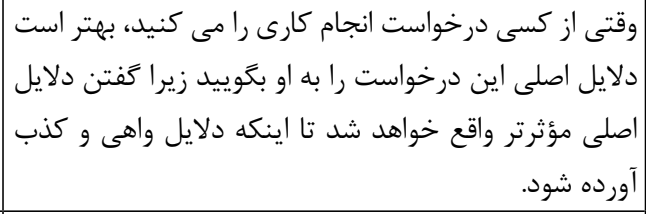 & $.1 \cdot$ \\
\hline & & & & & بارند. & .11 \\
\hline & & & & & خواهد داشت. & .14 \\
\hline & & & & & 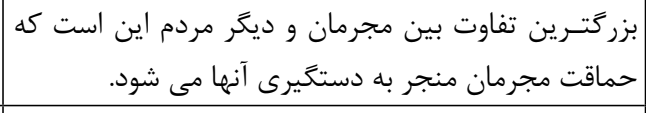 & . \\
\hline & & & & & بيشتر مردم شجاع هستند. & .14 \\
\hline & & & & & كرنش و جايلوسى در مقابل افراد مههم ، كارى عاقلانه است. & .10 \\
\hline & & & & & |استكه از همه جنبه ها بخواهيم خوب باشيم ، امكان يذير & .19 \\
\hline & & & & & كافى افراد ساده لوح وجود اين عبارت موافق هستيد: همواره در دنيا به اندازه & $.1 \mathrm{~V}$ \\
\hline & & & & & خدواهد بود. زدن از سر و ته كارها، يِيشرفت كردن امرى دشوار & .11 \\
\hline & & & & & 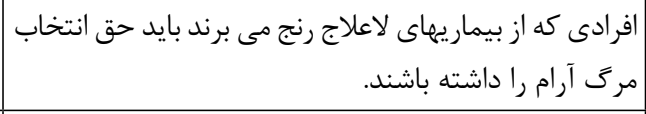 & .19 \\
\hline & & & & & 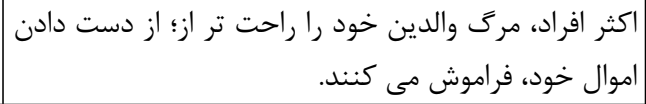 & .r. \\
\hline
\end{tabular}


دو فصلنامه حسابدارى ارزشى و رفتارى، سال ينجم، شماره دهم، پإييز و زمستان و9"1

سوالات مرتبط بادستكارى عاطفى : لطفاً ميزان دقيق موافقت يا عدم موافقت خود را با هر زويه با علامت ضربدر مشخص فرمائيد.

\begin{tabular}{|c|c|c|c|c|c|c|}
\hline & & 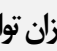 & & & & \\
\hline$\Delta$ & f & $r$ & $r$ & 1 & & \\
\hline 点 & $\frac{g}{: \frac{9}{2}}$ & $\begin{array}{l}: 3 \\
\frac{3}{3} \\
\frac{3}{2}\end{array}$ & .8 & 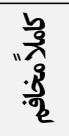 & كويه ها & .3 \\
\hline & & & & & |مى دانم كه جطور ديگران را خجالت زده كنم تاطور ديكرى & 1 \\
\hline & & & & & مى دانم جطور ديخران را ناراحت كنم. & r \\
\hline & & & & & مى دانم كه جطور باعث ايجاد اختلاف در ديخران شوم. & r \\
\hline & & & & & 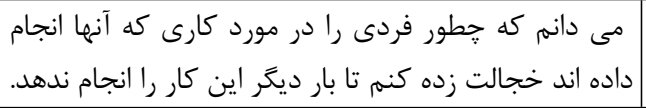 & f \\
\hline & & & & & كنمى مى دانم كه جطور اعضاى نزديك خانواده و دوستانم را اذيت & $\Delta$ \\
\hline & & & & & كنند مى توانم باعث نگرانى فرد شوم تا آنها طور ديخرى رفتار & q \\
\hline & & & & & 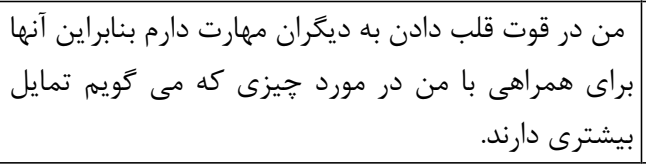 & $\mathrm{v}$ \\
\hline & & & & & 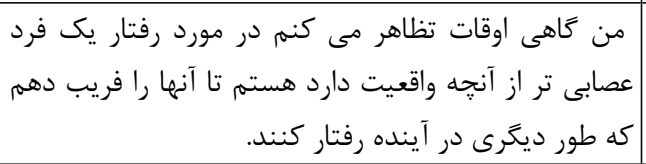 & $\wedge$ \\
\hline & & & & & 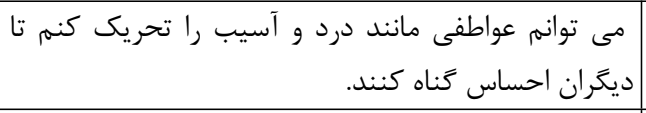 & 9 \\
\hline & & & & & 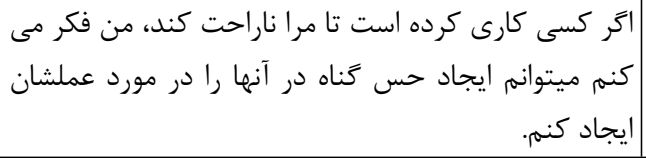 & 1 \\
\hline & & & & & 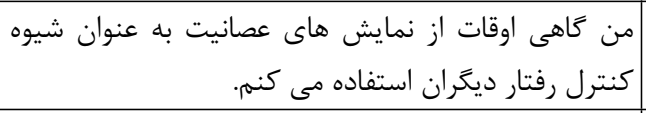 & 11 \\
\hline & & & & & مى حى توانم براى راضى كردن ديكران به انجام كارى كد & it \\
\hline
\end{tabular}




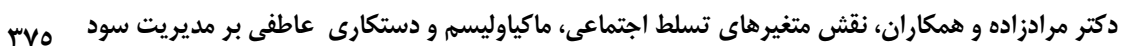

\begin{tabular}{|c|c|c|c|c|c|c|}
\hline \multicolumn{5}{|c|}{ 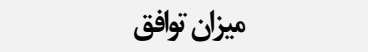 } & \multirow[b]{3}{*}{ كويه ها } & \multirow{3}{*}{.) } \\
\hline$\Delta$ & f & $r$ & $r$ & 1 & & \\
\hline 点 & $\frac{9}{9}$ & $\begin{array}{l}3 \\
3 \\
3 \\
\frac{3}{2}\end{array}$ & $\frac{19}{2}$ & 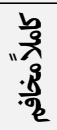 & & \\
\hline & & & & & 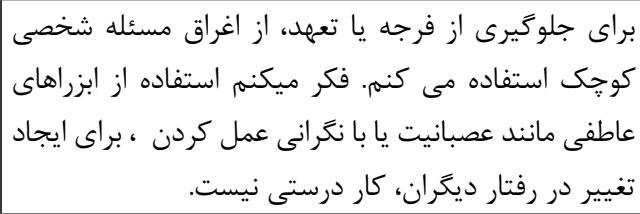 & Ir \\
\hline & & & & & من در انخيزه دادن به ديگران مهارت زيادى ندارم. & If \\
\hline & & & & & احساس مى كنم كه مهارت هاى عاطفى اندكى دارم. & 10 \\
\hline & & & & & 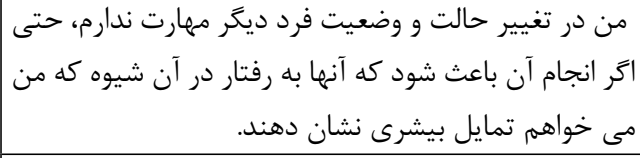 & 19 \\
\hline & & & & & من در تشويق مثبت ديخران مهارت زيادى ندارم. & IV \\
\hline & & & & & 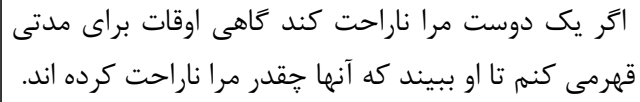 & 11 \\
\hline & & & & & خود را بى فردى ارزش كرا ناراحت يا عصبى كند، ميل دارم احساسات & 19 \\
\hline & & & & & ينهان مقى كنم. فردى مرا ناراحت يا عصبى كند، اغلب احساساسم را & r. \\
\hline & & & & & من كن اغلب احساسات خشم يا اضطراب را از ديخران مخفى & rI \\
\hline & & & & & 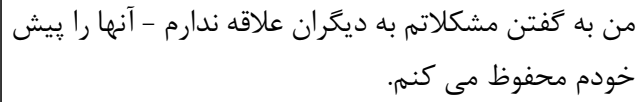 & tr \\
\hline
\end{tabular}

سوالات مرتبط با مديريت سود:

يس از مطالعه هر مسئله، با توجه به مقياس زير، عددى را كه بيانكر "نظر شخصى شما درباره رفتار مدير" مىباشد در كنار هر جمله بنويسيد.

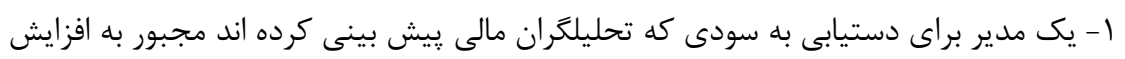
سود در كوتاه مدت است. شركت در حال حاضر نيازمند جذب سرمايه هاى سرمايه كذاران است. 


\begin{tabular}{|c|c|c|c|c|c|c|c|c|}
\hline \multicolumn{9}{|c|}{ د را براى دريافت يول و دستيابى } \\
\hline 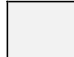 & 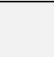 & 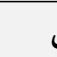 & ن توا & & & & \multirow{3}{*}{ كويه ها } & \multirow{3}{*}{$\stackrel{\hat{q}}{.}$} \\
\hline$V$ & 9 & $\Delta$ & $f$ & $r$ & $r$ & 1 & & \\
\hline \multirow[t]{4}{*}{$\frac{b}{d}$} & ?; & $\ddot{\vec{j}}$ & 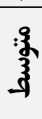 & $b_{2}$ & 争: & ${ }_{11} \bar{\lambda}$ & & \\
\hline & & & & & & & احتام دهم. اينكه من رفتارى مشابه رفتار مدير & .1 \\
\hline & & & & & & & مشابه رفتار مدير انجام دهند. احتمال اينكه ساير افراد رفتارى &.$r$ \\
\hline & & & & & & & شد تا حه حمد اختلاقى كه در؟ بالا به آن اشاره & r. \\
\hline
\end{tabular}

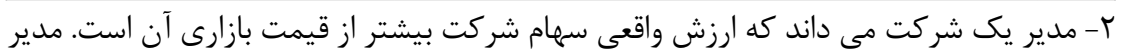

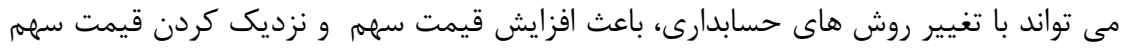

$$
\text { به ارزش واقعى آن شود. }
$$

رفتار مدير: مدير روش حسابدارى را تغيير مى دهد و باعث افزايش قيمت سهم مى شود

\begin{tabular}{|c|c|c|c|c|c|c|c|c|}
\hline \multicolumn{7}{|c|}{ ميزان توافق } & كويه ها & \multirow{3}{*}{$\hat{\hat{q}}$} \\
\hline 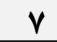 & 9 & $\Delta$ & 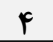 & $r$ & $r$ & 1 & & \\
\hline \multirow[t]{4}{*}{$\frac{b}{2}$} & ?ֶ; & 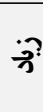 & : & $b_{k}$ & 3. & $1 \overline{\frac{3}{\pi}}$ & & \\
\hline & & & & & & & احتمال اينكه من رفتارى مشابه رفتار مدير & .1 \\
\hline & & & & & & & به نظر شما احتمال اينكه ساير افراد رفتارى &.$r$ \\
\hline & & & & & & & به نظر شما رفتارى كه در بالا به آن اشاره & $r$ \\
\hline
\end{tabular}

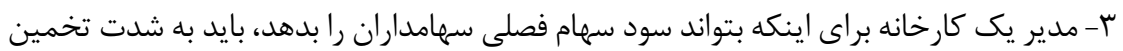

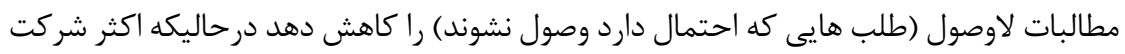

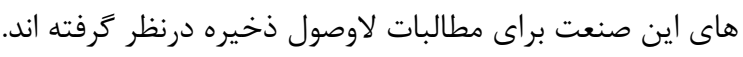

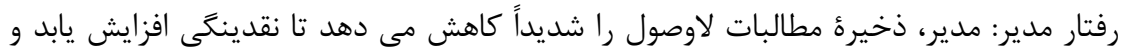
بتواند سود سهامداران را بيردازد. 


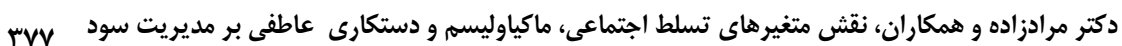

\begin{tabular}{|c|c|c|c|c|c|c|c|c|}
\hline \multicolumn{7}{|c|}{ ميزان توافق } & \multirow{3}{*}{ كويه ها } & \multirow{3}{*}{. } \\
\hline V & 9 & $\Delta$ & 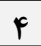 & $r$ & $r$ & 1 & & \\
\hline$\frac{b}{2}$ & $\begin{array}{l}3 \\
3 \\
3 \\
3\end{array}$ & $\dot{3}$ & :\$ & $b_{2}$ & $\begin{array}{l}3 \\
3 \\
z\end{array}$ & ${ }_{17} \overline{9}$ & & \\
\hline & & & & & & & احتمال اينكه من رفتارى مشابه رفتار مدير & .1 \\
\hline & & & & & & & مشابه رفتار مدير انجام دهندا احتمال اينكه ساير افراد رفتارى & r \\
\hline & & & & & & & 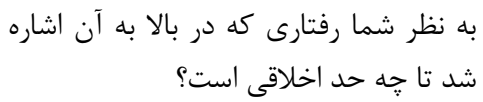 & r. \\
\hline
\end{tabular}

F- مدير متوجه شده است كه ارقام فروش فصلى برنامه ريزى شده محقق نخواهد شد؛ بنابراين وى ياداش دريافت نخواهد كرد. با اين وجود اگر كارمندان يك ماه اضافه كارى كنند، ارقام فروش محقق خواهد شد.

رفتار مدير: مدير به كارمندان دستور مى دهد كه يك ماه اضافه كارى كنند تا مدير بتواند ياداش

\begin{tabular}{|c|c|c|c|c|c|c|c|c|}
\hline \multicolumn{7}{|c|}{ ميزان توافق } & \multirow{3}{*}{ كويه ها } & \multirow{3}{*}{$\hat{\hat{j}}$} \\
\hline$V$ & 9 & $\Delta$ & $f$ & $r$ & $r$ & 1 & & \\
\hline$\stackrel{b}{a}$ & ?ִ & $\dot{3}$ & : & $b_{2}$ & לy: & ${ }_{11} \overline{\frac{9}{2}}$ & & \\
\hline & & & & & & & |احتمال اينكه من رفتارى مشابه رفتار مدير & .1 \\
\hline & & & & & & & مشابه رفتار مدير انجام دهند احتمال اينكه ساير افراد رفتارى & tr \\
\hline & & & & & & & 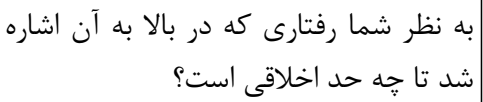 & r. \\
\hline
\end{tabular}

ه- در يك شركت توليدى، از آنجايى كه هزينه هاى شركت و پاداش مدير مستقيماً باهم در

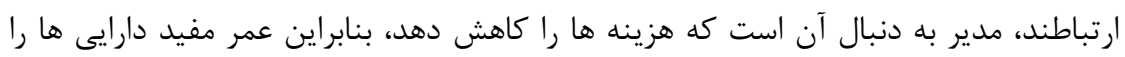
برخلاف روش معمول در آن صنعت به كونه اى محاسبه مى كند كه هزينه ها كاهش يابند و مدير به ياداش خود برسد. رفتار مدير: مدير با تغيير روش محاسبة استتهلاك (محاسبة عمر مفيد دارايى ها)، به ياداش خود برد دست مى يابد. 
دو فصلنامه حسابدارى ارزشى و رفتارى، سال ينجم، شماره دهم، پإييز و زمستان و9"1

\begin{tabular}{|c|c|c|c|c|c|c|c|c|}
\hline \multicolumn{7}{|c|}{ ميزان توافق } & \multirow{3}{*}{ كويه ها } & \multirow[b]{3}{*}{$\hat{\grave{j}}$} \\
\hline$v$ & 9 & $\Delta$ & $F$ & $r$ & $r$ & 1 & & \\
\hline \multirow[t]{3}{*}{$\frac{b}{d x}$} & îj: & ? & :\$ & $b_{2}$ & 象; & ${ }_{12} \overline{\frac{9}{2}}$ & & \\
\hline & & & & & & & |احتمال اينكه من رفتارى مشابه رفتار مدير & .1 \\
\hline & & & & & & & بهابه رفتار مدير احتمام دهند. اينكه ساير افراد رفتارى &.$r$ \\
\hline & & & & & & & شد تا حهـ حمد رفتارى كه در بالا به به آن اشاره & $r$ \\
\hline
\end{tabular}

צ- در صورتى كه فروش شركت به حد معينى در ماه برسد مدير در يست مديريتى خود باقى مى ماند.

رفتار مدير: مدير هزينه هاى جانبى از جمله هزينه تبليغات را تا حدى بالا مى برد كه به فروش مورد نظر دست يابد و ֶست مديريتى خود را حفظ كند.

\begin{tabular}{|c|c|c|c|c|c|c|c|c|}
\hline \multicolumn{7}{|c|}{ ميزان توافق } & \multirow{3}{*}{ كويه ها } & \multirow{3}{*}{ ) } \\
\hline$v$ & 9 & $\Delta$ & $f$ & $r$ & $r$ & 1 & & \\
\hline$\frac{b}{\lambda}$ & î; & $\dot{3}$ & 条 & $v_{k}$ & 3̂; & ${ }_{\| \bar{n}} \bar{q}$ & & \\
\hline & & & & & & & احتجام دهم. اينكه من رفتارى مشابه رفتار مدير & .1 \\
\hline & & & & & & & مشابه رفتار مدير انجام دهند. احتمال اينكه ساير افراد رفتارى &.$r$ \\
\hline & & & & & & & شد تا حه حمد اخلاقى است؟ كر بالا به آن اشاره & r. \\
\hline
\end{tabular}

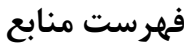

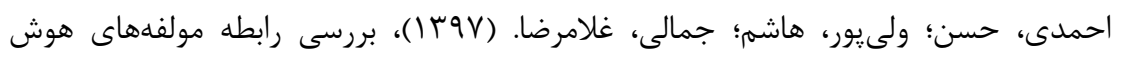
هيجانى تهيه كنند

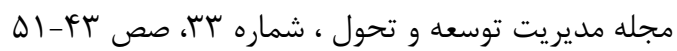


دكتر مرادزاده و همكاران، نقش متغيرهاى تسلط اجتماعى، ماكياوليسم و دستكارى عاطفى بر مديريت سود

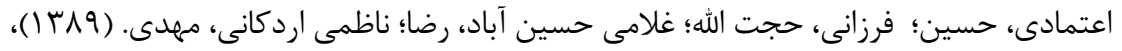

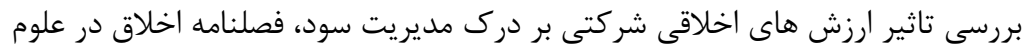

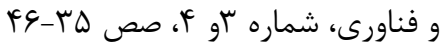

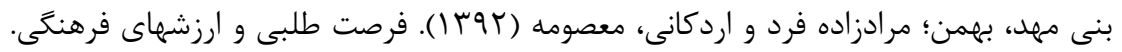

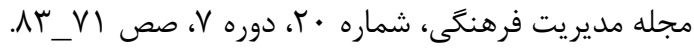

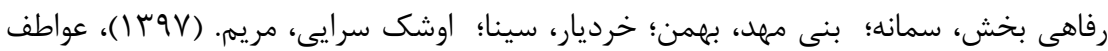
فردى و رفتار مديريت سود : آزمونى از نظريه روانشناسى مثبت كرائ سرا، دو فصلنامه

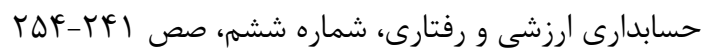

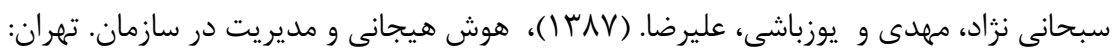
انتشارات سيطرون

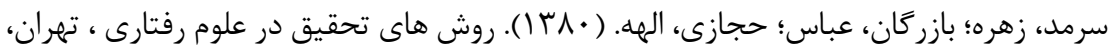

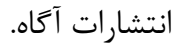

شاهدحسين، سمانه؛ خان محمدى، محمدحامد؛ محموديان دستنايى، طاهره. (191 (1). تبيين

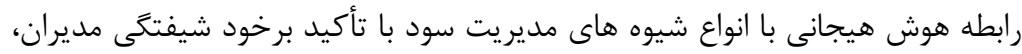

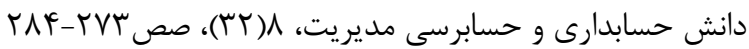

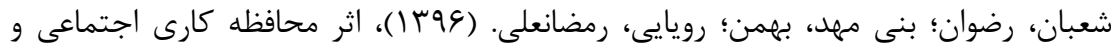

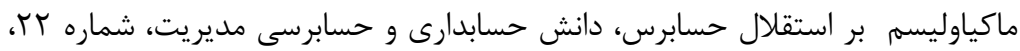

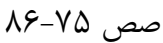

صادقيان، مسعود؛ بنى مهد، بهمن؛ جهانگيرنيا، حسين؛ غلامى جمكرانى، رضا. (1) (1)،

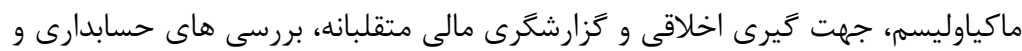

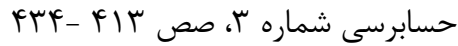

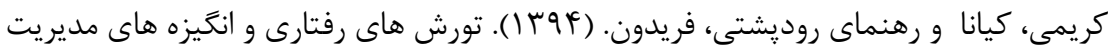

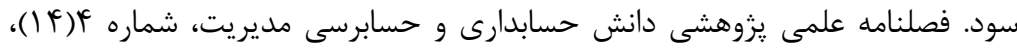

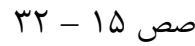

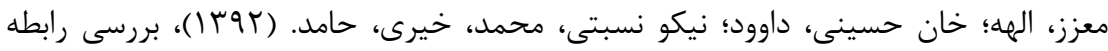

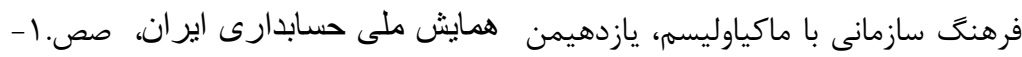

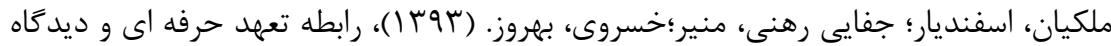

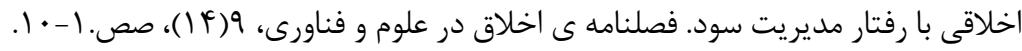




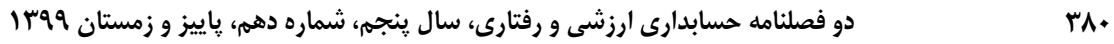

$$
\begin{aligned}
& \text { منصورزارع ، مينو ؛ بنى مهد ، بهمن ؛ وكيلى فرد ، حميدرضا ؛ رهنماى روديشتى ، فريدون }
\end{aligned}
$$

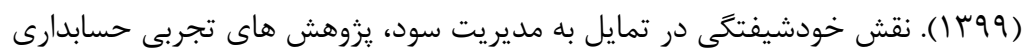

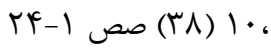

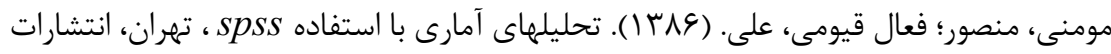

$$
\begin{aligned}
& \text { كتاب نو. }
\end{aligned}
$$

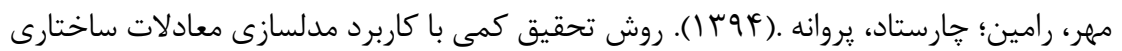

$$
\begin{aligned}
& \text { ، ت تهران، انتشارات ترمه. } \\
& \text { نخى آبادى، مصطفى؛ نصيرزاده، فرزانه. (99 (1). شخصيت ماكياوليستى و مديريت سود: با تاكيد } \\
& \text { بر سبك رهبرى اخلاقى، هجدهمين همايش ملى حسابدارى ايران، يزد. }
\end{aligned}
$$

Austin, E. J., Farrelly, D., Black, C., and , H. Moore. 2007.Emotional intelligence, Machiavellianism and emotional manipulation: Does EI have a dark side? journal of Personality and Individual Differences 43(1): 179-189.

Azouzi, M.A.and A.Jarboui.2012.CEO Emotional Intelligence and board of directors Efficiency. Iranian Journal of Management Studies 5 (2) $: 115-144$.

Birkás, B., Csathó, Á., B.,Gács, and T.Bereczkei.2015.Nothing ventured nothing gained: Strong associations between reward sensitivity and two measures of Machiavellianism. Personality and Individual Differences, 74: 112-115.

Belski W, J. Beams, J. Brozovsky .2008. Ethical Judgments in Accounting: An Examination on the Ethics of Managed Earnings Journal of Global Business Issues 2(2): 59-68.

Boduszek, D., A. Debowska,., and A. Willmott. 2017 . Latent profile analysis of psychopathic traits among homicide, general violent, property and white-collar offenders. J. Crim. Justice. 51: 17-23.

Bradberry, T., and J.Greave. 2005. Emotional intelligence quick book. Translated by: M. Ganji. Tehran: Savalan Publication. Denham SA, K.A Blair, E. DeMulder, J. Levitas, K .Sawyer, Auerbach-Major S.;1; 2003. Preschool emotional competence: pathway to social competence. Child Dev. 74:238-56.

Chen, S. 2010. Relations of Machiavellianism with emotional blackmail orientation of salespeople, Procedia Social and Behavioral Sciences. 5 : 294-298

Christie, R., and, F. Geis, L. 2013. Studies in machiavellianism. Academic Press.

Daff , L., P,D .Lange. 2012. A comparison of genetic skills and emotional intelligence in accounting educatiH. and Lin, $\mathrm{K}-\mathrm{Y}$. 'Ethical perceptions 
on earnings management', Int. J. Behavioural Accounting and Finance, 3(4) :163-187.

De Hooge, I. E., S. M.Breugelmans and M. Zeelenberg, .2008.Not so ugly after all: When shame acts as commitment device. Journal of Personality and Social Psychology, 95(4): 933-943.

D'Souza , M.F., and G.S.F De Lima.2015.The Dark Side of Power : The dark Triad in Opportunistic Decision- Making, ASAA JOURNAL Advances in Scientific and Applied Accounting, 8(2) : 135-156

Duckitt ; j .2001.A dual-process cognitive-motivational theory of ideology and prejudice. advances in experimental social Psychology;33:41-113

Esmaeili, H., B .Banimahd.,and , S. Kheradyar .2019. The role of machiavellianism, emotional and manipulation and moral foundation in tax avoidance. Iranian Journal of finance 3(1): 53-72

Feng, M., Ge, W., Luo, S., Shevlin, T.2011. Why do CFOs become involved in material accounting manipulations? Journal of Accounting and Economics (51): 21-36.

Forgas, J.1995. Mood and judgment: The Affect Infusion Model (AIM) Psychological Bulletin, 117(1):39-66

Grieve , R., E .March , G. Van Doorn .2019. Masculinity might be more toxic than we think: The influence of gender roles on trait emotional manipulation, journal of Personality and Individual Differences 138 : $157-162$

Gruenfeld, D.H., Inesi , M. E. , J. C Magee,.and , A.D. Galinsky .2008.Power and the objectification of social targets. Journal of Personality and Social Psychology, 95(1): 111-127.

Ham, Ch., Lang, M., N.,Seybert, S. Wang.2017. CFO Narcissism and Financial Reporting Quality. Available at https://ssrn.com/abstract $=2581157$

Hartmann, F. G., and , V. S Maas. 2010. Why business unit controllers create budget slack: involvement in management, social pressure, and machiavellianism. Behavioral research in accounting, 22(2): 27-49.

Healy , P., and J. M. Wahlen. 1999. A review of the earnings managemant literature and its implications for standard setting. Accounting Horizons, 13(4) : 143-147

Inesi , M. e .2010. Power and loss aversion. Organizational Behavior and Human Decision Processes , 112 (1) : 58-69

Jensen , M., and W. Meckling.1976. Theory of the firm : Managerial behavior , agency costs and ownership structure. Journal of Financial economics , 3(4) : 305-360

Jones, D. N., and , D. L Paulhus. 2009. Machiavellianism. In M. R. Leary \& R. H. Hoyle (Eds.),Handbook of individual differences in social behavior :93-108 
Jones, S.and R. Sharma. 2001. "The impact of free cash flow, financial leverage and accounting regulation on earnings management in Australia's "old" and "new" economies", Managerial Finance, 27(12): 18-39

Lee,K.and,M.CAshton.2005.Psychopathy,Machiavellianism and narcissism in the Five-Factor model and the HEXCO model of personality structure. Personality and Individual Differences, 38:1571-1582

Leung, K., and M. H Bond .2004.Social axioms: A model for social beliefs in multicultural perspective. Advances in Experimental Social Psychology, 36:119-197.

Magner, N., , R. B., Welker and T. L. Campbell .1996. Testing a model of cognitive budgetary participation processes in a latent variable structural equations framework. Accounting and Business Research, 27(1): 41-50.

MesmerMagnus, J. R., and L. DeChurch, A.2009.Information Sharing and Team Performance: A Meta-Analysis. Journal of AppliedPsychology,94(2):535-546.

Murphy,P.R.2012.Attitude,Machiavellianism and the rationalization of misreporting, Accounting, Organizations and Society $37: 242-259$

Pratto, F., J., Sidanius, and S.Levin.2006. Social dominance theory and the dynamics of intergroup relations: Taking stock and looking forward. European Review of Social Psychology, 17:271-320.

Pruysersa, S., Blaisb ,J.,P.G.Chen .2019. Who makes a good citizen? The role of personality, Personality and Individual Differences 146 :99104

Ruiz-Palomino, P., and A. Banon-Gomis, 2017. The negative impact of chameleon-inducing personalities on employees' ethical work intentions: The mediating role of Machiavellianism. European Management Journal, 35(1): 102-115.

Rodriguez-Bailon, R., M., Moya, and V.Yzerbyt.2000.Why do superiors attend to negative stereotypic information about their subordinates? Effects of power legitimacy on social perception.European Journal of Social Psychology, 30(5): 651-671.

Ryckman, R. M.2007.Theories of personality. Belmont: Thomson Wadsworth

Sayal, K. and Singh, G. 2020. Investigating the role of theory of planned behavior and Machiavellianism in earnings management intentions, Accounting Research Journal, 33(6): 653-668.

Scott, R.W. Financial Accounting Theory, New Jersey: Prentice Hall.

Dalton, D.W. 2021. The Effects of Machiavellianism and Ethical Environment on Whistle-blowing across Low and High Moral 
دكتر مرادزاده و همكاران، نقش متغيرهاى تسلط اجتماعى، ماكياوليسم و دستكارى عاطفى بر مديريت سود سرب

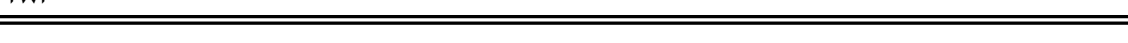
Intensity Settings, Advances in Accounting Behavioral Research,24(1):29-49

Shafer W.E. Z Wang, .2011. Effects of ethical context and Machiavellianism on attitudes toward earnings management in China, Managerial Auditing Journal 26(5) : $372-392$.

Shafer, W. E., \& Wang, Z.2018. Machiavellianism, social norms, and taxpayer compliance , Business Ethics: A European Review , 27 : 4255

Stevens, G. Deuling W, J. K., . A. and Armenakis .2012. Successful psychopaths: Are they unethical decision-makers and why? Journal of Business Ethics, 105: 139-149

Verbeek, M.., A. boon and, P. dredt 1996. Exploration, aggressive behavior and dominance in pair_wise confrotations of juvenile male great tits. Behavior 133:945 963.

Wastell,C., and A. Booth,.2003.Machiavellianism:An alexithymia perspective. Journal of Social and Psychology, 22: 730-744Clinical 